
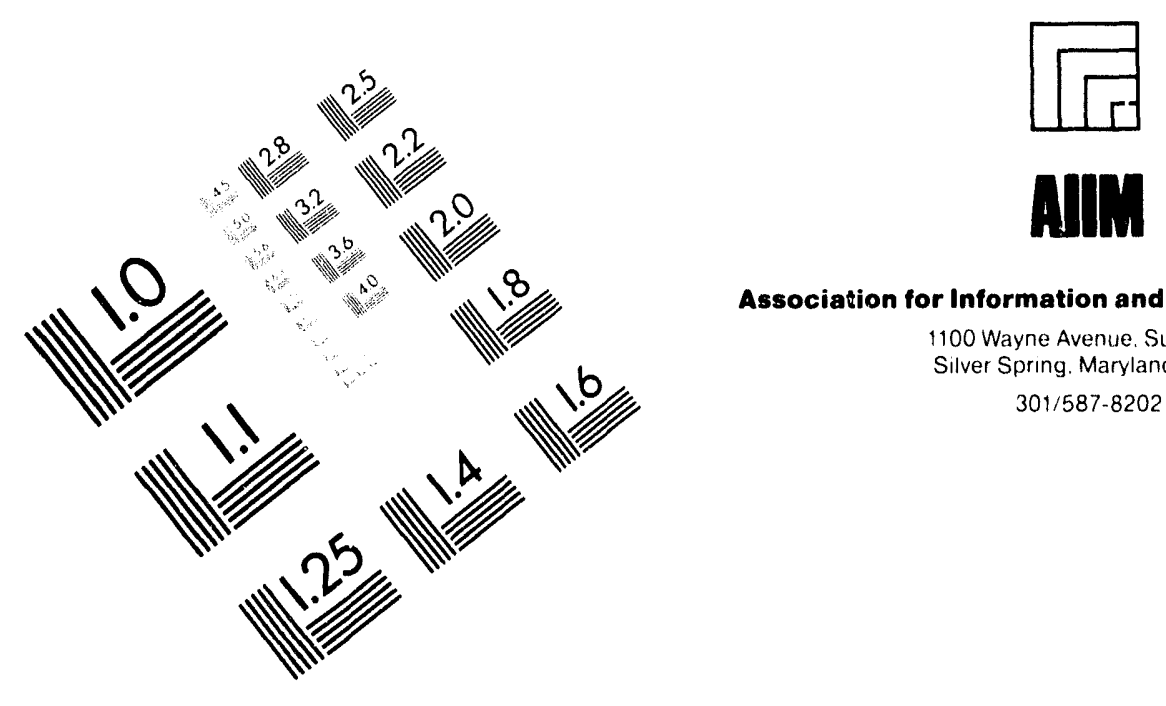

Association for Information and Image Management

1100 Wayne Avenue. Suite 1100

Silver Spring. Maryland 20910

301/587-8202

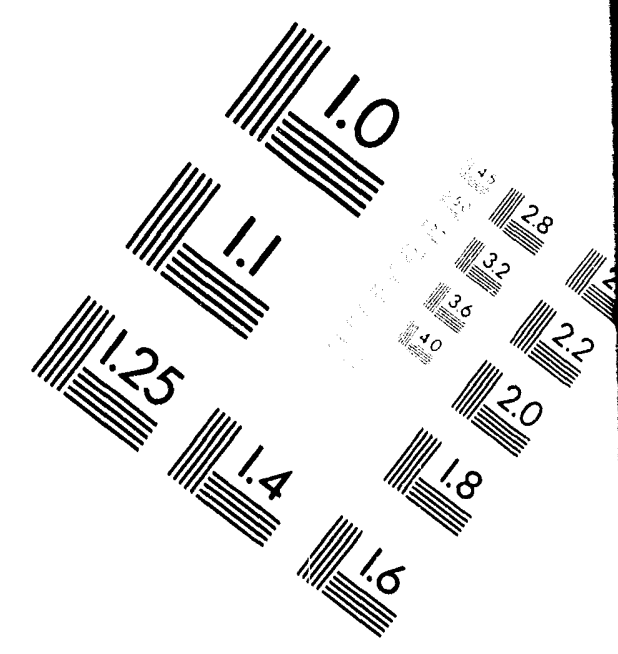

\title{
Centimeter
}

$\begin{array}{llllllllllllllll}1 & 2 & 3 & 4 & 5 & 6 & 7 & 8 & 9 & 10 & 11 & 12 & 13 & 14 & 15 & \mathrm{~mm}\end{array}$

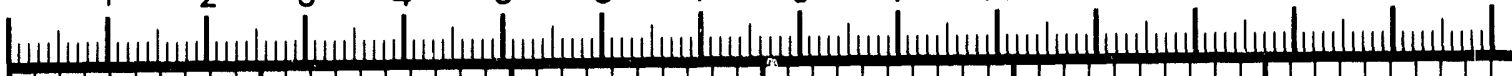

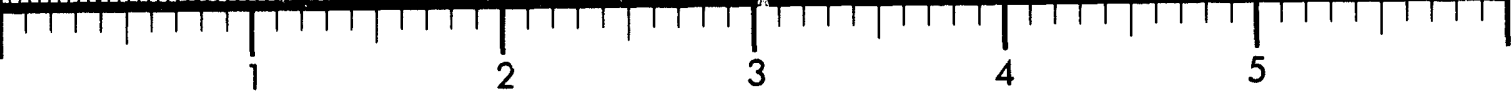

Inches
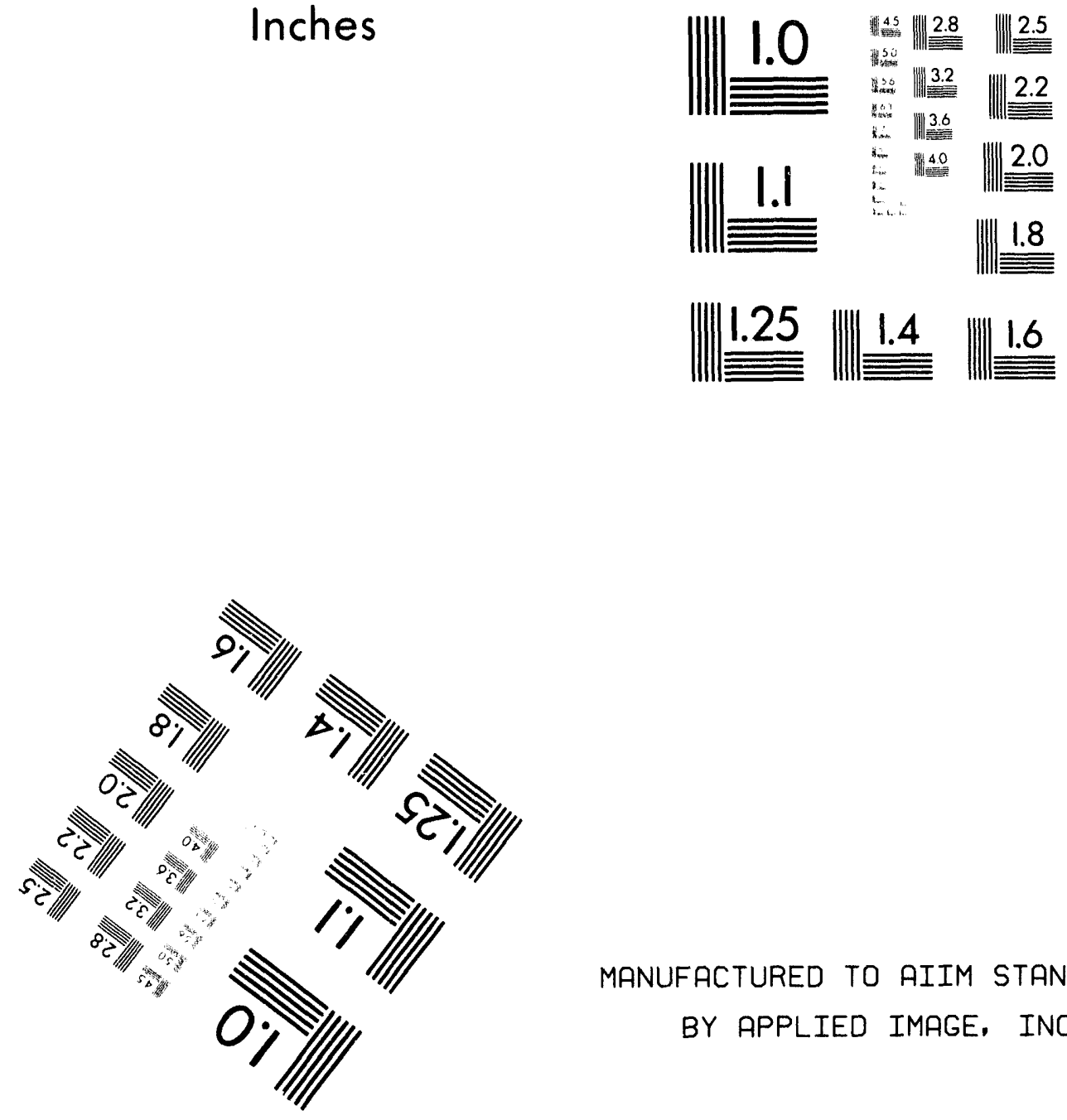

MANUFACTURED TO AIIM STANDARDS

BY APPLIED IMAGE, INC.

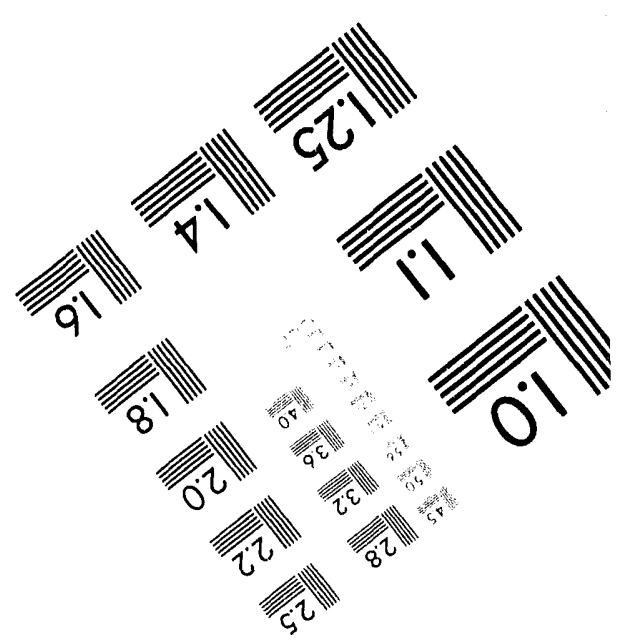



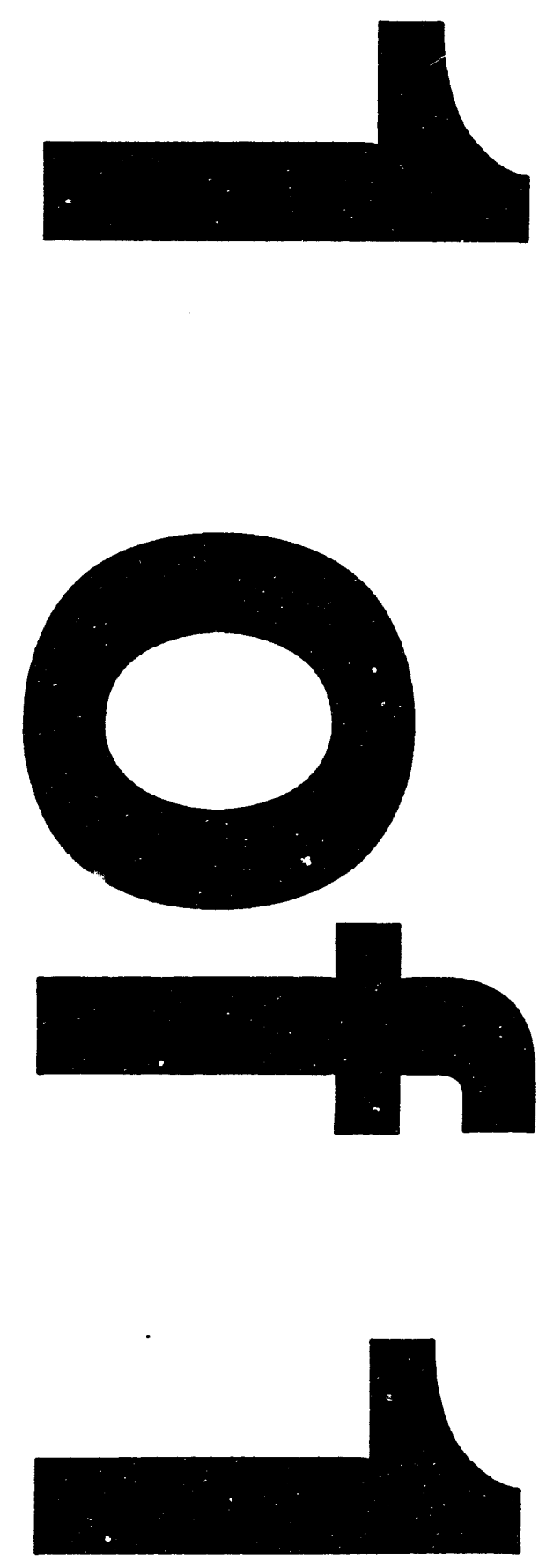


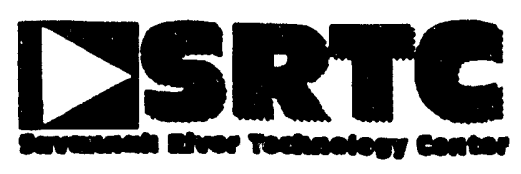

WSRC-RP-93-1315

\section{A PARAMETRIC STUDY OF SMOKE PROPAGATION USING THE CFAST COMPUTER CODE (U)}

September 1993

\section{Patent Status}

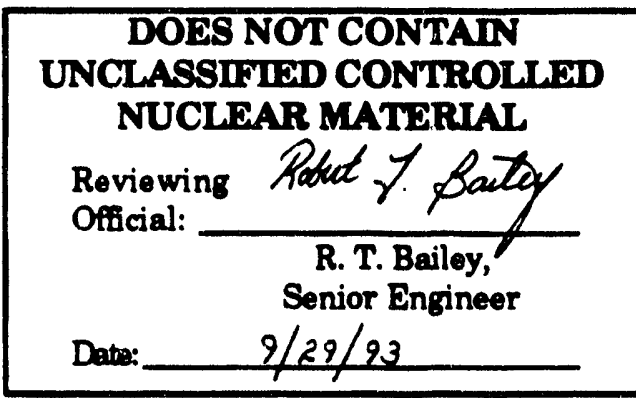

This internal management report is boing transmitted without DOE patent clearance, and no further dissemination or publication shall be made of the repon without prior approval of the DOE.SR patent council.

Westinghouse Savannah River Company Savannah River Sto Alken, SC 29808

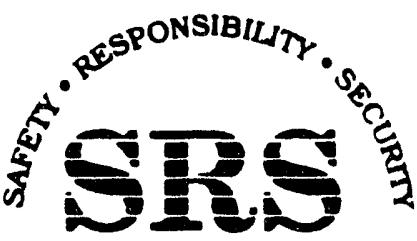

SAVANNAH RIVER SITE

PREPARED FOR THE U.S. DEPARTMENT OF ENERGY UNDER CONTRACT NO. DE-ACO9-89SR18035 


\section{DISCLAIMER}

This report was prepared by Westinghouse Savannah River Company
(WSRC) for the United States Department of Energy under Contract No.
DE-AC09-89SR18035 and is an account of work performed under that
contract. Neither the United States Department of Energy, nor WSRC, nor
any of their employees makes any warranty, expressed or implied, or
assumes any legal liability or responsibility for the accuracy,
completeness, or usefulness, of any information, apparatus, or product or
process disclosed herein or represents that its use will not infringe
privately owned rights. Reference herein to any specific commercial
product, process, or service by trademark, name, manufacturer or
otherwise does not necessarily constitute or imply endorsement,
recommendation, or favoring of same by WSRC or by the United States
Government or any agency thereof. The views and opinions of the authors
expressed herein do not necessarily state or reflect those of the United States
Government or any agency thereof.




\section{A PARAMETRIC STUDY OF SMOKE PROPAGATION USING THE CFAST COMPUTER CODE (U)}

by

D. A. Kalinich

R. T. Bailey

Issued: September 1993

Westinghouse Savannah Rlver Company

Savannah River Site

Alken, SC 29808

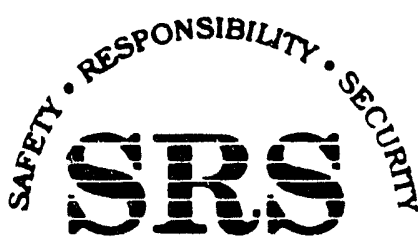

SAVANNAH RIVER SITE

PREPARED FOR THE U.S. DEPARTMENT OF ENERGY UNDER CONTRACT NO. DE-ACO9-89SR18035 


\section{WSRC-RP-83-1315}

This page intentionally left blank. 
Project:

Document:

Title:
ERPD Smoke/Fire Modeling

WSRC-RP-93-1315

A PARAMETRIC STUDY OF SMOKE PROPAGATION USNGG THE CFAST COMPUTHR CODE (U)

Approvals:

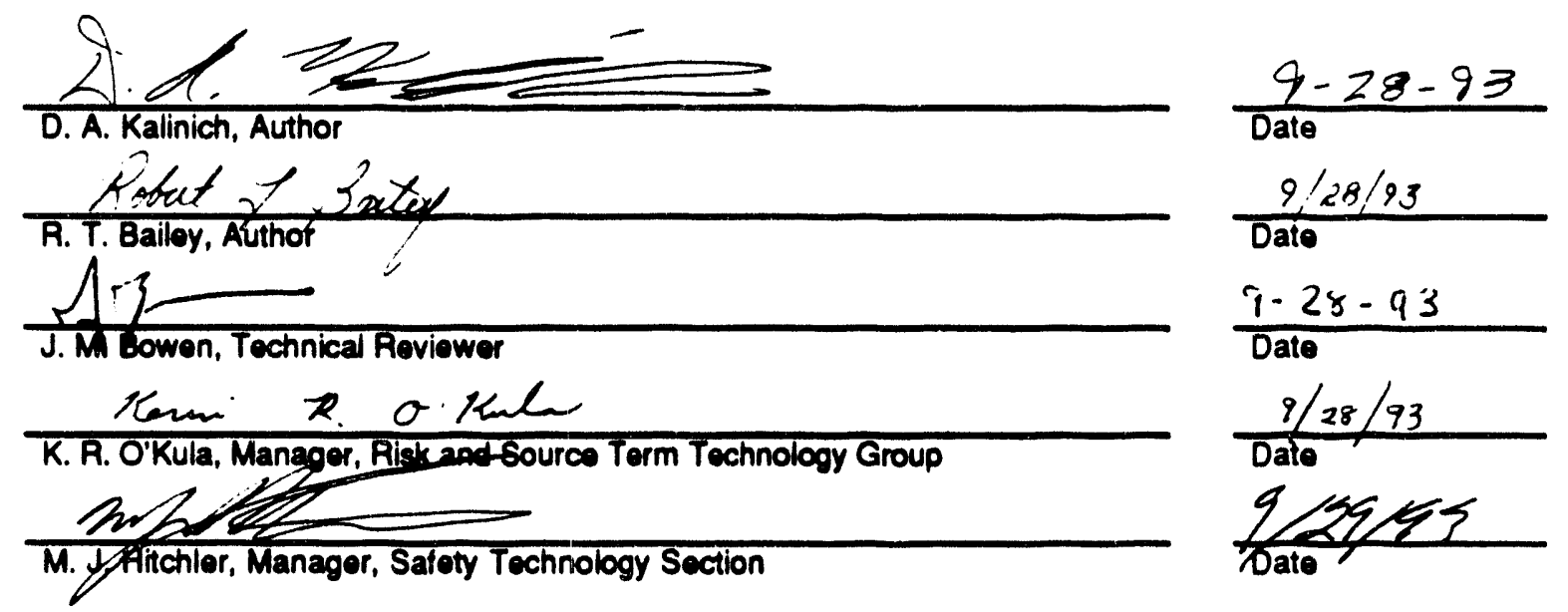


WSRC-RP.93-1315

This page intentionally left blank. 


\section{EXECUTIVE SUMMMARY}

In order to provide additional data to assist fire protection engineers in performing Fire Hazards Analyses (FHAs), the Risk and Source Term Technology (R\&STT) Group of Westinghouse Savannah River Company (WSRC) has conducted a parametric study of smoke propagation in a single-room/adjacent-hallway geometry. The computer code CFAST (Consolidated Model of Fire Growth And Smoke Transport) [1], developed by the National Institute for Standards and Technology (NIST), was used to perform the calculations. Three parameters were varied in the study:

- the room area $\left(10-25 \mathrm{~m}^{2}\right)$;

- the hallway length (5-15 m); and

- the rate of heat release from the fire $(100-600 \mathrm{~kW})$.

The room forced-ventilation flow rate, the room and hallway heights, and the hallway width were all fixed. The effects of the three parameters above on the following six quantities were investigated:

- the steady-state temperature of the upper (hot gas) layer in both the room containing the fire and the hallway;

- the steady-state layer interface height (i.e., the distance from the bottom of the upper layer to the floor) in both the room containing the fire and the hallway;

- the time for the layer interface height to reach $1.75 \mathrm{~m}$ in both the room containing the fire and the hallway.

The results of the calculations are presented as a series of $\mathbf{2 4}$ graphs, each demonstrating a different aspect of the parametric study. Based on these results, the following conclusions were drawn:

- The dominant parameter affecting the layer interface height and upper layer temperature in both the fire room and the hallway is the fire heat generation rate.

- The hallway length has little if any effect on the layer interface height or the upper layer temperature in the fire room at steadystate conditions nor does it influence the time it takes for the layer interface in the fire room to drop to $1.75 \mathrm{~m}$.

- In general, increasing the area of the fire room or the hallway length will cause the layer interface to attain a higher steady-state height and take longer to drop to $1.75 \mathrm{~m}$, as well as causing a decrease in the upper layer temperature. 
- In general, increasing the fire heat generation rate will cause the layer interface to attain a lower steady-state height and take less time to drop to $1.75 \mathrm{~m}$, as well as causing an increase in the upper layer temperature.

Suggestions regarding future work include modifying the fire model to provide a more realistic simulation of actual fire conditions, expanding the model geometry to include additional rooms, and parametrically varying the force ventilation system parameters. 
TABLE OF CONTENTS

EXECUTIVE SUMMARY $1-1$

1.0 INTRODUCTION

2.0 DESCRIPTION OF CFAST CODE AND PARAMETRIC MODEL.......... 2-1

2.1 Code Description......................................................... 2 -

2.2 Model Description.

3.0 PARAMETRIC ANALYSIS...............................................

3.1 Problem Parameters and Calculation Methodology.................... 3-1

3.2 Results .................................................................... $3-3$

4.0 CONCLUSIONS AND RECOMMENDATIONS............................. 4

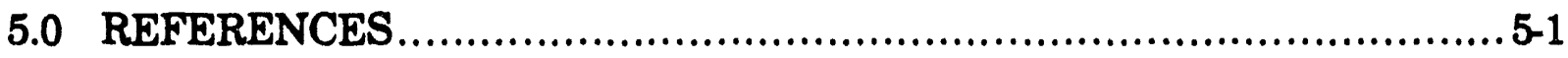




\section{LIST OF FTGURES}

2-1. Sketch of the CFAST Parametric Model.......................................... 2-2

3-1. Fire Room Layer Interface Height at $600 \mathrm{~s}\left(10 \mathrm{~m}^{2}\right.$ Fire Room)........... 36

3-2. Fire Room Layer Interface Height at $600 \mathrm{~s}\left(15 \mathrm{~m}^{2}\right.$ Fire Room)........... 36

3-3. Fire Room Layer Interface Height at $600 \mathrm{~s}\left(20 \mathrm{~m}^{2}\right.$ Fire Room)............ 3-7

3-4. Fire Room Layer Interface Height at $600 \mathrm{~s}\left(25 \mathrm{~m}^{2}\right.$ Fire Room)........... 3-7

3-5. Hallway Layer Interface Height at $600 \mathrm{~s}\left(10 \mathrm{~m}^{2}\right.$ Fire Room).............. 3-8

3-6. Hallway Layer Interface Height at $600 \mathrm{~s}$ (15 $\mathrm{m}^{2}$ Fire Room).............. 3-8

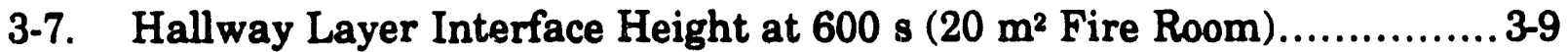

3-8. Hallway Layer Interface Height at $600 \mathrm{~s}\left(25 \mathrm{~m}^{2}\right.$ Fire Room).............. 3-9

3-9. Fire Room Upper Layer Temperature at $600 \mathrm{~s}$ (10 $\mathrm{m}^{2}$ Fire Room).

3-10. Fire Room Upper Layer Temperature at $600 \mathrm{~s}$ (15 $\mathrm{m}^{2}$ Fire Room)

3-11. Fire Room Upper Layer Temperature at $600 \mathrm{~s}$ (20 $\mathrm{m}^{2}$ Fire Room)

3-12. Fire Room Upper Layer Temperature at $600 \mathrm{~s}$ (25 $\mathrm{m}^{2}$ Fire Room).

3-13. Hallway Upper Layer Temperature at $600 \mathrm{~s}$ (10 $\mathrm{m}^{2}$ Fire Room).........3-12

3-14. Hallway Upper Layer Temperature at $600 \mathrm{~s}$ (15 $\mathrm{m}^{2}$ Fire Room)..........3-12

3-15. Hallway Upper Layer Temperature at $600 \mathrm{~s}\left(20 \mathrm{~m}^{2}\right.$ Fire Room)..........3-13

3-16. Hallway Upper Layer Temperature at $600 \mathrm{~s}\left(25 \mathrm{~m}^{2}\right.$ Fire Room).........3-13

3-17. Time for Layer Interface Height to Drop to $1.75 \mathrm{~m}$ in the Fire Room (10 $\mathrm{m}^{2}$ Fire Room)

3-18. Time for Layer Interface Height to Drop to $1.75 \mathrm{~m}$ in the Fire Room (15 $\mathrm{m}^{2}$ Fire Room)

3-19. Time for Layer Interface Height to Drop to $1.75 \mathrm{~m}$ in the Fire Room (20 $\mathrm{m}^{2}$ Fire Room) 
3-20. Time for Layer Interface Height to Drop to $1.75 \mathrm{~m}$ in the Fire Room ( $25 \mathrm{~m}^{2}$ Fire Room)

3-21. Time for Layer Interface Height to Drop to $1.75 \mathrm{~m}$ in the Hallway ( $10 \mathrm{~m}^{2}$ Fire Room)

3-22. Time for Layer Interface Height to Drop to $1.75 \mathrm{~m}$ in the Hallway ( $15 \mathrm{~m}^{2}$ Fire Room)

3-23. Time for Layer Interface Height to Drop to $1.75 \mathrm{~m}$ in the Hallway $\left(20 \mathrm{~m}^{2}\right.$ Fire Room)

3-24. Time for Layer Interface Height to Drop to $1.75 \mathrm{~m}$ in the Hallway ( $25 \mathrm{~m}^{2}$ Fire Room) 


\section{LIST OF TABLES}

Page

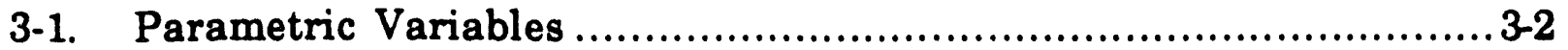




\subsection{INTRODUCTION}

When performing a Fire Hazards Analysis (FHA), fire protection engineers are often interested in determining the degree and timing of smoke propagation from one room to another within buildings. Often, the engineer must make judgments based on a limited set of guidelines and available information.

In order to provide additional data to assist in these judgments, the Risk and Source Term Technology (R\&STT) Group of Westinghouse Savannah River Company (WSRC) has conducted a parametric study of smoke propagation in a single-room/adjacent-hallway geometry. The computer code CFAST (Consolidated Model of Fire Growth And Smoke Transport) [1], developed by the National Institute for Standards and Technology (NIST), was used to perform the calculations. Three parameters were varied in the study:

- the room area;

- the hallway length; and

- the rate of heat release from the fire.

The room forced-ventilation flow rate, the room and hallway heights, and the hallway width were all fixed. The effects of the three parameters above on the following six quantities were investigated:

(1) the steady-state temperature of the upper (hot gas) layer in the room containing the fire;

(2) the steady-state layer interface height (i.e., the distance from the bottom of the upper layer to the floor) in the room containing the fire;

(3) the time for the layer interface height to reach $1.75 \mathrm{~m}$ in the room containing the fire;

(4) temperature of the upper (hot gas) layer in the hallway;

(5) the steady-state layer interface height (i.e., the distance from the bottom of the upper layer to the floor) in the hallway;

(6) the time for the layer interface height to reach $1.75 \mathrm{~m}$ in the hallway;

In the next section (Section 2), the CFAST model used in this study is described in detail. Section 3 gives the results of the analyses in the form of 24 graphs with accompanying textual commentary. Section 4 presents conclusions based on these results and offers suggestions for future work. Finally, Section 5 lists the references for the report. 
This page intentionally left blank. 


\section{DESCRIPTION OF CFAST CODE AND PARAMETRIC MODEL}

Brief descriptions of the CFAST code and the associated parametric model used in this study are provided in Sections 2.1 and 2.2, respectively.

\subsection{Code Description}

The CFAST (Consolidated Model of Fire Growth And Smoke Transport) computer code [1] was developed at the National Institute of Standards and Technology (NIST) as a merger of the FAST [2] and CCFM.VENTS [3] development projects. CFAST is a zone model code, meaning that each room is divided into a small number of volumes, each of which is assumed to have uniform properties. Based on experimental observations, the rooms in CFAST are divided into two zones-an upper (hot gas) and lower (cooler gas) layer.

The time-dependent conservation equations for the layer mass and enthalpy are solved along with the equation of state. At room boundaries (doors, vents, etc.), the Bernoulli equation is solved to determine the momentum transfer between zones. Various approximate models are used to handle physical phenomena such as fire plumes, door jets, ceiling jets, vent flow, and species concentration and deposition. Convection, radiation, and conduction heat transfer between the gas and walls of a room are also modeled [1].

\section{Model Description}

Since this work was performed as a "generic" parametric study, no particular facility was modeled. However the results from this work are intended to be used in Fire Hazards Analysis (FHA) walk-downs of office buildings. With this in mind, an effort was made to develop the model so that the study results would be applicable for that purpose.

The parametric model (shown in Figure 2-1) consists of two room volumes and an environment volume, along with a forced ventilation system. The room containing the fire is intended to be representative of a typical office/conference room, while the other room represents a hallway leading from the fire room to the environment. Fresh air is delivered to the fire room via the fan and duct systen. The floor was assumed to be concrete, while the walls and ceiling were assumed to be made of gypsum sheet rock. A detailed description of the model inputs is given in Section 3.1. 


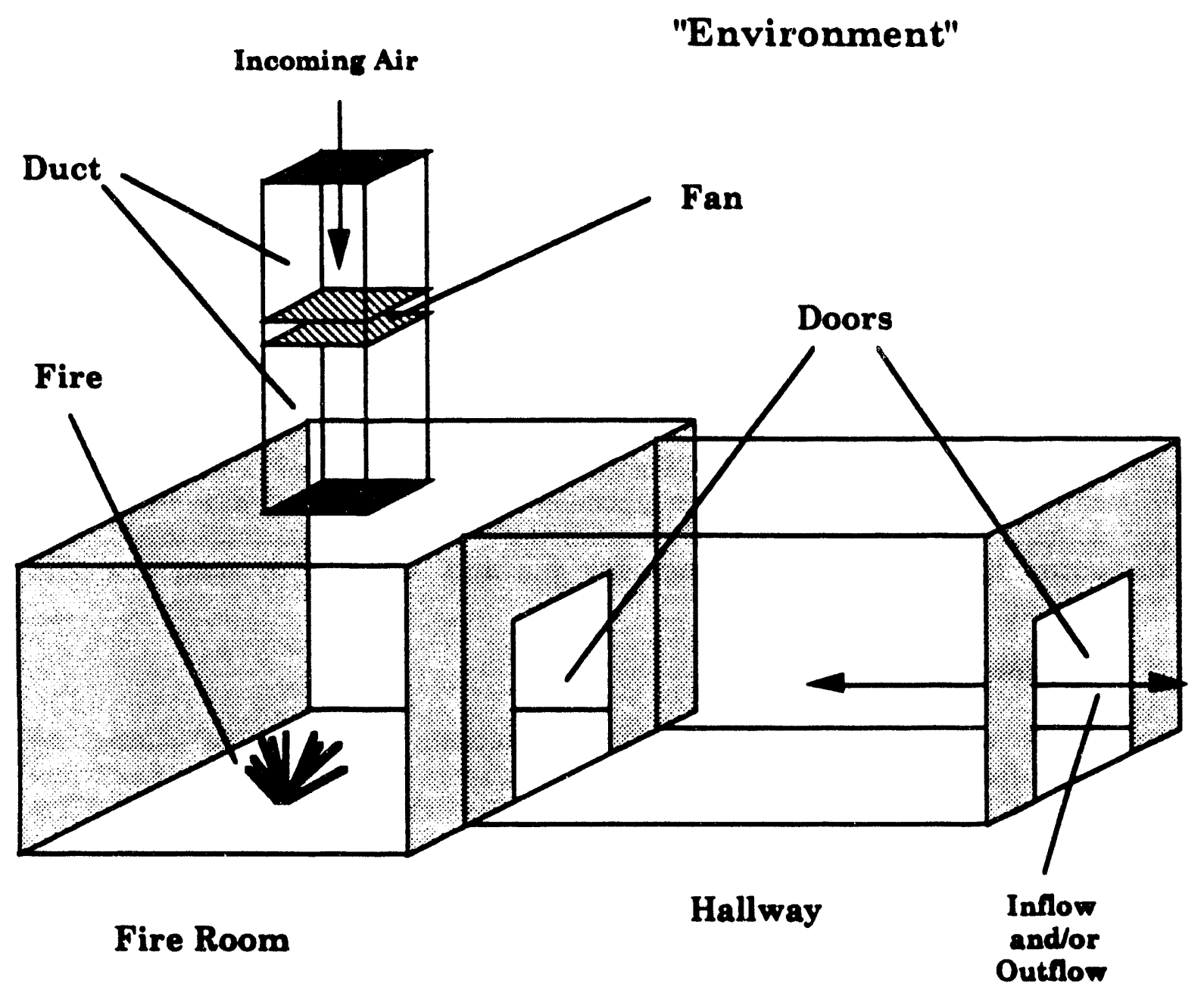

Figure 2-1

Stretch of the CFAST Parametric Model 


\subsection{PARAMETRIC ANALYSIS}

The model inputs and the manner in which they were varied, along with the calculation methodology are discussed in Section 3.1. The results from the parametric study are given in Section 3.2.

\subsection{Problem Parameters and Calculation Methodology}

For this study, the (1) fire room area; (2) hallway length; and (3) heat generation rate of the fire were investigated as to their affect on the upperlayer temperature and layer interface height (i.e., distance from the bottom of the smoke layer to the floor) in both the fire room and the hallway. Table 3-1 lists the values of the aforementioned parameters used in the test cases that were run. All $\mathbf{4 8}$ combinations of these parameters were considered.

The other inputs to the CFAST model were held constant for all of the test cases. These inputs are discussed below.

\section{Initial Conditions}

The default CFAST initial conditions were used.

- Room, hallway, and environment temperatures: $300 \mathrm{~K}$

- Room, hallway, and environment pressures: 101,300 Pa

Room Geometry

Room geometry was chosen to be representative of typical office buildings. For similarity, the length and width of the fire room were set equal.

- Fire room and hallway height: $3.0 \mathrm{~m}$

- Hallway width: $2.0 \mathrm{~m}$

- Door height: $2.0 \mathrm{~m}$

- Door width: $1.0 \mathrm{~m}$

Ventilation System

A simple ventilation system was incorporated into the parametric model. The duct area, duct length, and the ventilation flow velocity were chosen to be representative of those found in typical office buildings [4].

- Duct areas: $0.1 \mathrm{~m}^{2}$

- Duct lengths: $1.0 \mathrm{~m}$

- Ventilation flow velocity: $0.076 \mathrm{~m} / \mathrm{s}$ 


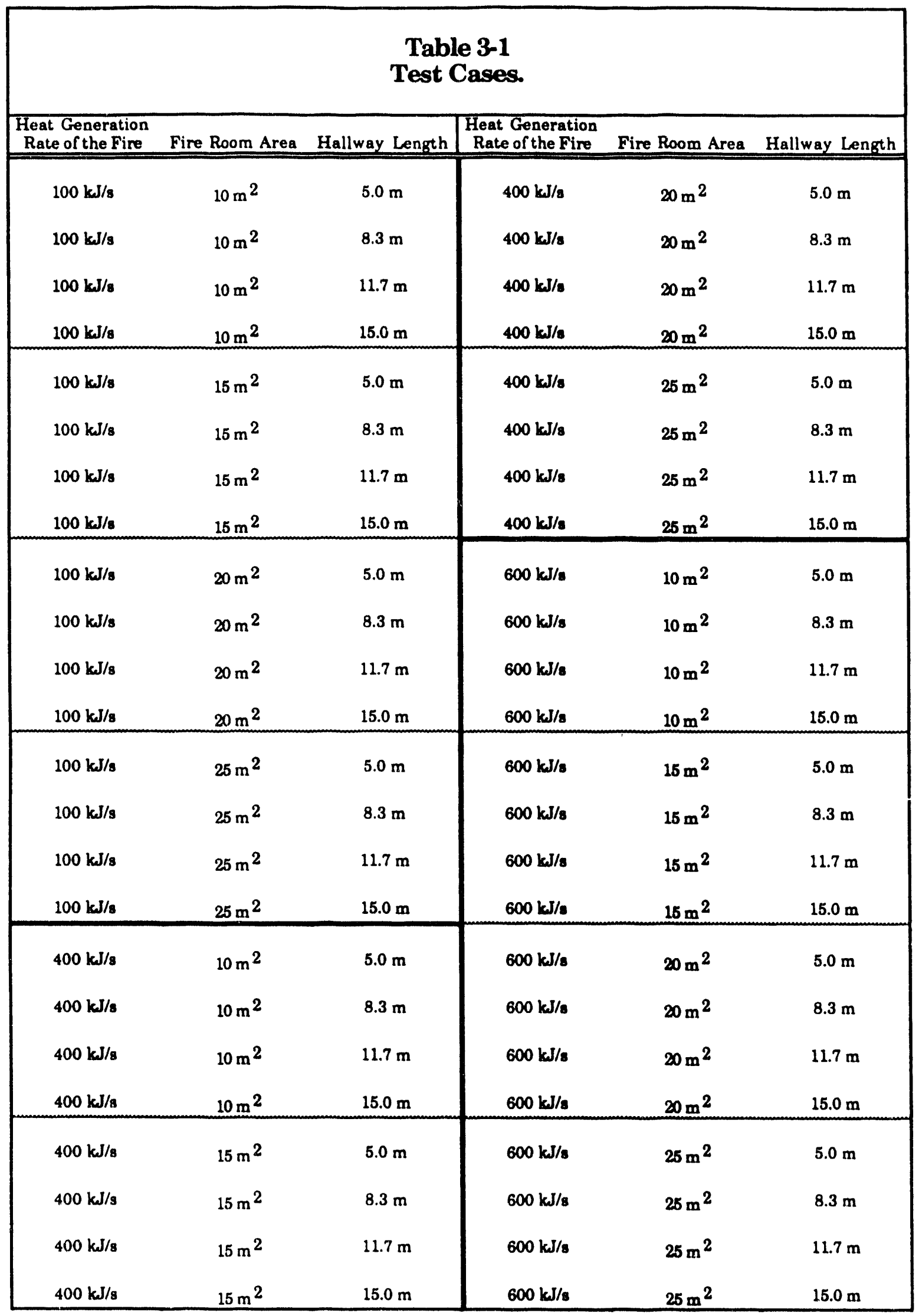


Materials

The materials that make up the floors, walls, and ceilings of the rooms have to be specified. This information is used to determine material properties necessary for heat transfer calculations.

- Walls and ceiling of the fire room and hallway: gypsum

- Floor of the fire room and hallway: concrete

Fire

The fire was modeled to begin at the start of the simulation. The fire heat generation rate was increased linearly from $t=0 \mathrm{~s}$ to $t=60 \mathrm{~s}$, after which it was held constant. By modeling the fire as unconstrained (i.e., its heat generation rate is independent of the supply of oxygen to the fire), the specified time-history of the fire is maintained during the calculation.

A set of CFAST input decks was developed for the parametric study. Based on preliminary runs, it was found to be necessary to run the test cases out to $600 \mathrm{~s}$ (simulation time) in order to achieve steady-state solutions.

\subsection{Results}

The results of the test cases are presented in a graphical format. The following data from the test cases were plotted as functions of the parametric variables:

- layer interface height in both the fire room and the hallway;

- temperature of the upper layer in both the fire room and the hallway; and

- the time it took for the layer interface to drop to 1.75 meters. (This interface height was chosen as representative of the height below which the smoke layer would threaten life safety.)

\section{Layer Interface Height}

Figures 3-1 to 3-4 show the fire room layer interface height at the $600 \mathrm{~s}$. A comparison of the figures finds that the heat generation rate is the dominant parameter affecting the interface height, while hallway length and fire room area have a very minimal effect. With a $10 \mathrm{~m}^{2}$ fire room, a heat generation rate of $600 \mathrm{~kJ} / \mathrm{s}$ causes the interface to drop to $\sim 0.55 \mathrm{~m}$; while with a $25 \mathrm{~m}^{2}$ fire room and a heat generation rate of $100 \mathrm{~kJ} / \mathrm{s}$, the interface drops down to only $-1.05 \mathrm{~m}$.

This same trend occurs in the hallway layer interface height data, but with the heat generation rate showing a lesser effect on interface height (see 
Figures 3-5 to 3-8). Here, for the cases cliscussed above, the layer interface drops to $\sim 1.05 \mathrm{~m}$ and $\sim 1.25 \mathrm{~m}$ respectively.

Looking at the small effect of hallway length, it is seen that increasing the hallway length causes a slight rise in the layer interface height. Conversely, increasing the fire room area is found to cause a slight decrease in layer interface height.

\section{Upper Layer Temperature}

Figures 3-9 to 3-12 show the temperature of the upper layer in the fire room at $600 \mathrm{~s}$. This time, the hallway length is seen to have no effect on the upper layer temperature. However, fire room area shows a noticeable affect on the upper layer temperature in that, as the fire room area is increased, its upper layer temperature decreases. At a fire heat generation rate of $600 \mathrm{~kJ} / \mathrm{s}$, the upper layer temperature is $\sim 425{ }^{\circ} \mathrm{C}$ in the $10 \mathrm{~m}^{2}$ fire room while it is $\sim 330^{\circ} \mathrm{C}$ in the $25 \mathrm{~m}^{2}$. fire room. As exp scted, the fire heat generation rate also affects the upper layer temperature. From the data, it is seen that an increase in fire heat generation rate leads to higher upper layer temperatures. For the case with the $10 \mathrm{~m}^{2}$ fire room (Figure 3-9), a fire heat generation rate of $600 \mathrm{~kJ} / \mathrm{s}$ leads to an upper layer temperature of $-425{ }^{\circ} \mathrm{C}$, while a rate of $100 \mathrm{~kJ} / \mathrm{s}$ yields an upper layer temperature of $-150^{\circ} \mathrm{C}$.

Turning to the hallway upper layer temperature results (see Figures 3-13 to $3-16$ ), the same general trends are seen, with the exception that the hallway length now has a noticeable effect on the upper layer temperature; an increase in hallway length leads to a decrease in upper layer temperature. For the case with the $25 \mathrm{~m}^{2}$ fire room (Figure 3-16) and a fire heat generation rate of $600 \mathrm{~kJ} / \mathrm{s}$, a hallway length of $5 \mathrm{~m}$ leads to an upper layer temperature of $\sim 260^{\circ} \mathrm{C}$. Increasing the hallway length to $15 \mathrm{~m}$ causes the layer temperature to decrease $\sim 20^{\circ} \mathrm{C}$ to $\sim 240^{\circ} \mathrm{C}$.

\section{Time for layer interface to drop to $1.75 \mathrm{~m}$}

Figures 3-17 to 3-20 show the time for the fire room layer interface height to drop to $1.75 \mathrm{~m}$. Once again, the hallway length has no discernible effect on the data within the fire room. Increasing the area of the fire room increases the time it takes the layer interface to reach $1.75 \mathrm{~m}$. For a fire heat generation rate of $100 \mathrm{~kJ} / \mathrm{s}$, the interface layer reaches $1.75 \mathrm{~m}$ in $\sim 13 \mathrm{~s}$ when the fire room area is $10 \mathrm{~m}^{2}$, while it takes $\sim 27 \mathrm{~s}$ when the fire room size is increased to $25 \mathrm{~m}^{2}$. As one might expect, an increase in the fire heat generation rate decreases the time it takes the interface layer to reach $1.75 \mathrm{~m}$. With a fire room size of $25 \mathrm{~m}^{2}$ (Figure 3-20), a $100 \mathrm{~kJ} / \mathrm{s}$ fire rate has the layer interface reaching $1.75 \mathrm{~m}$ in $\sim 27 \mathrm{~s}$; increasing the rate to $600 \mathrm{~kJ} / \mathrm{s}$ reduces the time for the layer interface to reach $1.75 \mathrm{~m}$ to $-17 \mathrm{~s}$.

In the hallway, the layer interface is affected by the hallway length, as well as the fire room size and fire heat generation rate. From Figures 3-21 to 3-24, the data show that increasing the length of the hallway increases the 
time it takes for the layer interface to reach $1.75 \mathrm{~m}$. In the case with the $10 \mathrm{~m}^{2}$ fire room (Figure 3-21) and a fire heat generation rate of $100 \mathrm{~kJ} / \mathrm{s}$, it takes $\sim 30 \mathrm{~s}$ for the interface layer to reach $1.75 \mathrm{~m}$. Increasing the hallway length to $15 \mathrm{~m}$ increases the time it takes the interface layer to reach $1.75 \mathrm{~m}$ to $\sim 45 \mathrm{~s}$. The effects of the fire room size and fire heat generation rate on the hallway layer interface are similar to those described above for the fire room layer interface. With a fire room area of $25 \mathrm{~m}^{2}$ (Figure 3-24) and a hallway length of $15 \mathrm{~m}$, a $600 \mathrm{~kJ} / \mathrm{s}$ fire heat generation rate causes the layer interface to drop to $1.75 \mathrm{~m}$ in $\sim 35 \mathrm{~s}$. For a rate of $100 \mathrm{~kJ} / \mathrm{s}$, it takes the layer interface $\sim 65 \mathrm{~s}$ to reach $1.75 \mathrm{~m}$. If the hallway length and fire heat generation rate are held constant at $5 \mathrm{~m}$ and $100 \mathrm{~kJ} / \mathrm{s}$, respectively, for the $10 \mathrm{~m}^{2}$ fire room (Figure 3-21), the hallway layer interface reaches $1.75 \mathrm{~m}$ in $\sim 30 \mathrm{~s}$; for the $25 \mathrm{~m}^{2}$ room (Figure 3-24), it takes $\sim 45 \mathrm{~s}$ for the layer interface to reach $1.75 \mathrm{~m}$ for the same hallway length/fire conditions. 
WSRC-RP-83-1315

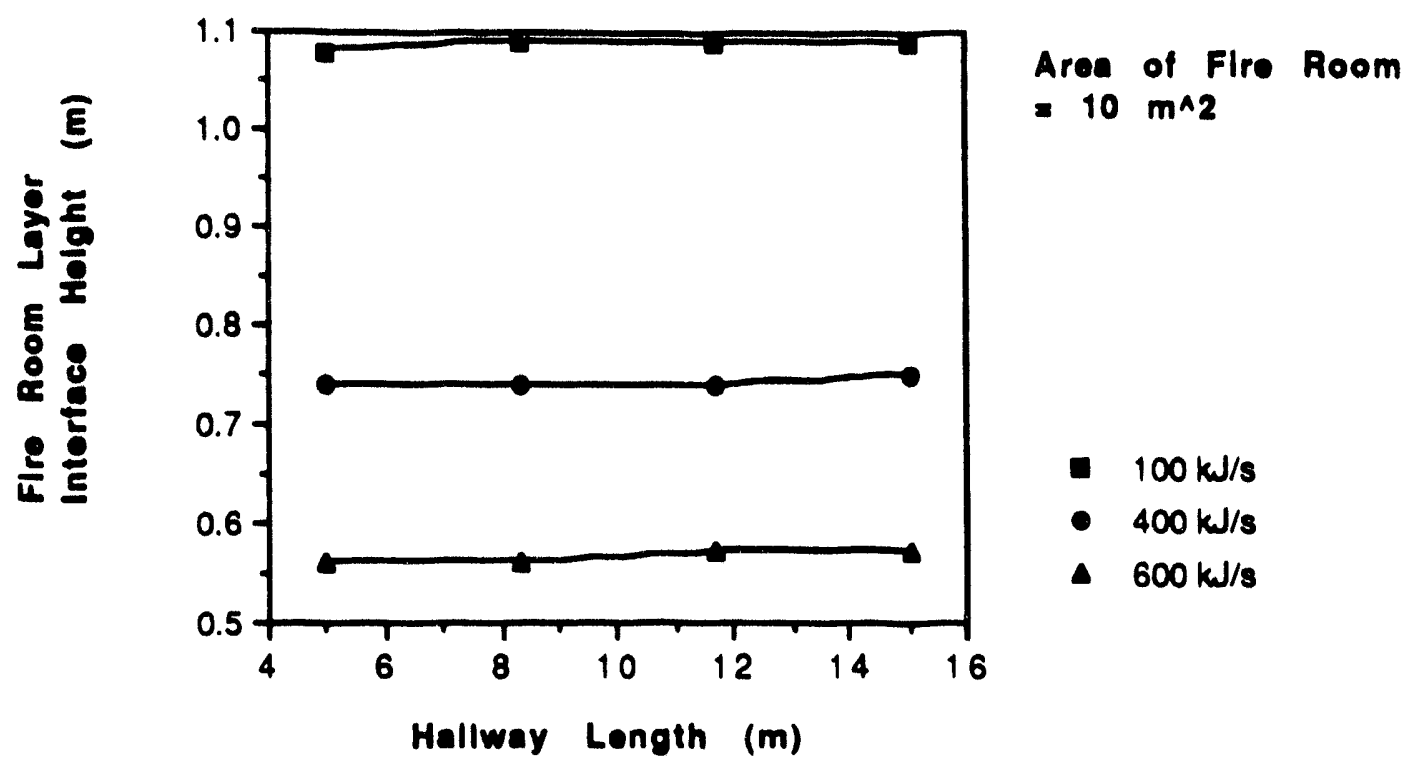

Figure 3-1

Fire Room Layer Interface Height at 600 s (10 m² Fire Room).

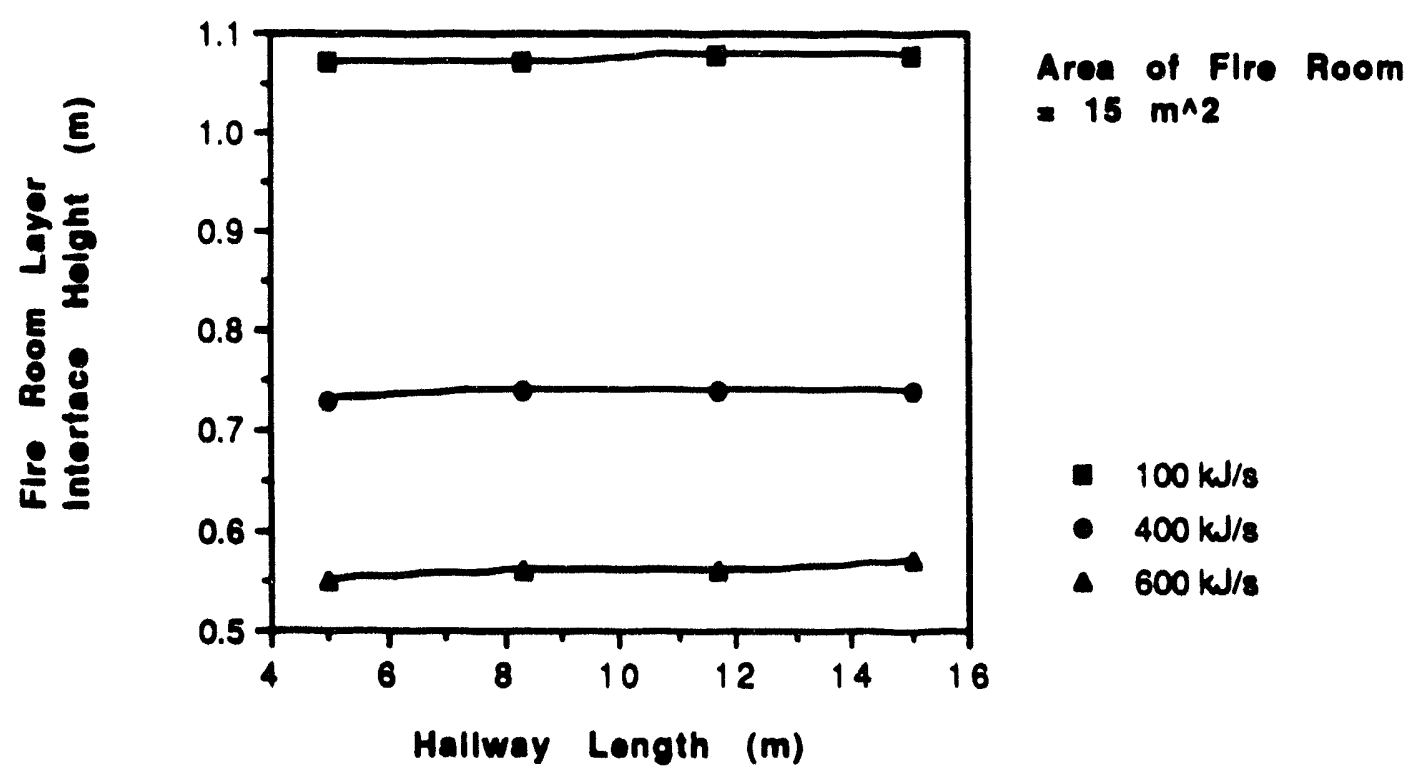

Figure 3-2

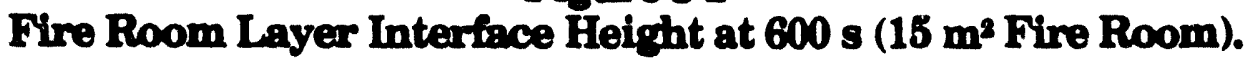


WSRC-RP.93-1315

$E$
$5=$
$3 \frac{2}{8}$
88
$\frac{8}{2}$

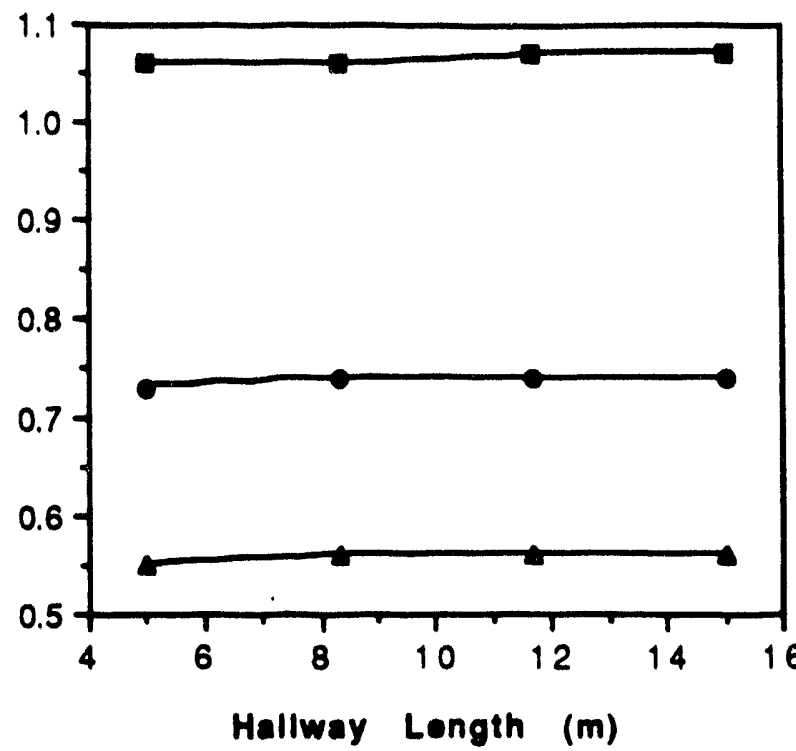

Aree of Fire Room

$=20 m^{\wedge} 2$

- $100 \mathrm{~kJ} / \mathrm{s}$

- $400 \mathrm{~kJ} / \mathrm{s}$

- $600 \mathrm{~kJ} / \mathrm{s}$

\section{Figure 3-3}

Fire Room Layer Interface Height at $600 \mathrm{~s}$ (20 m² Fire Room).

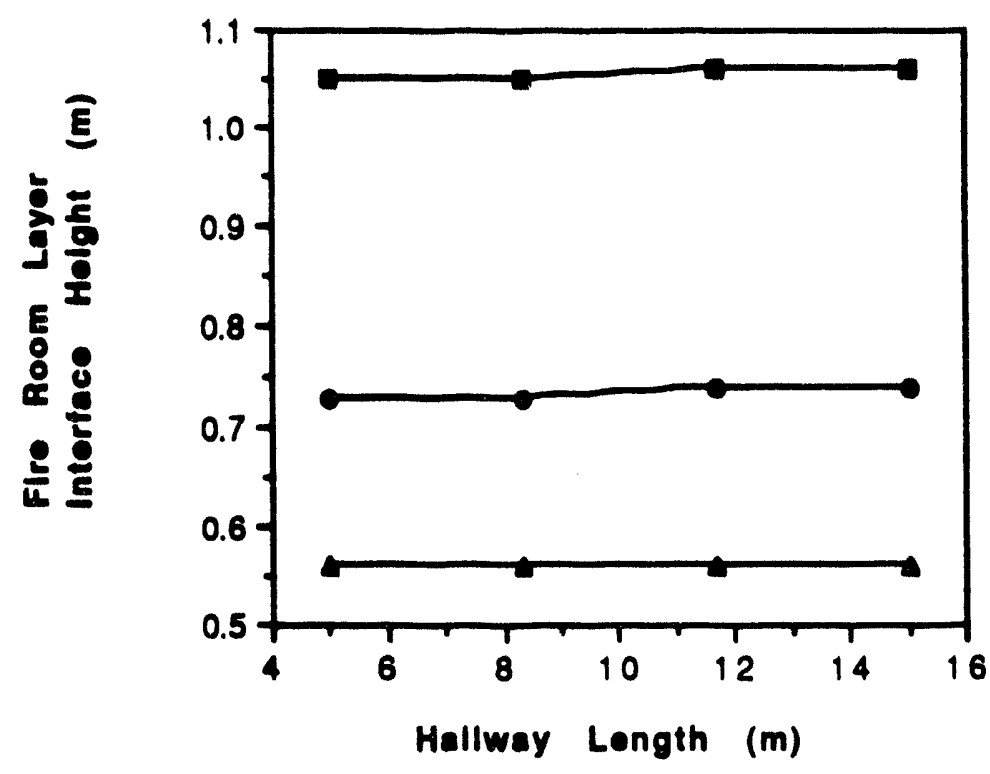

Area of Fire Room

- 25 m^2

Figure 3-4

Fire Room Layer Interface Height at $600 \mathrm{~s}$ (25 $\mathrm{m}^{2}$ Fire Room). 


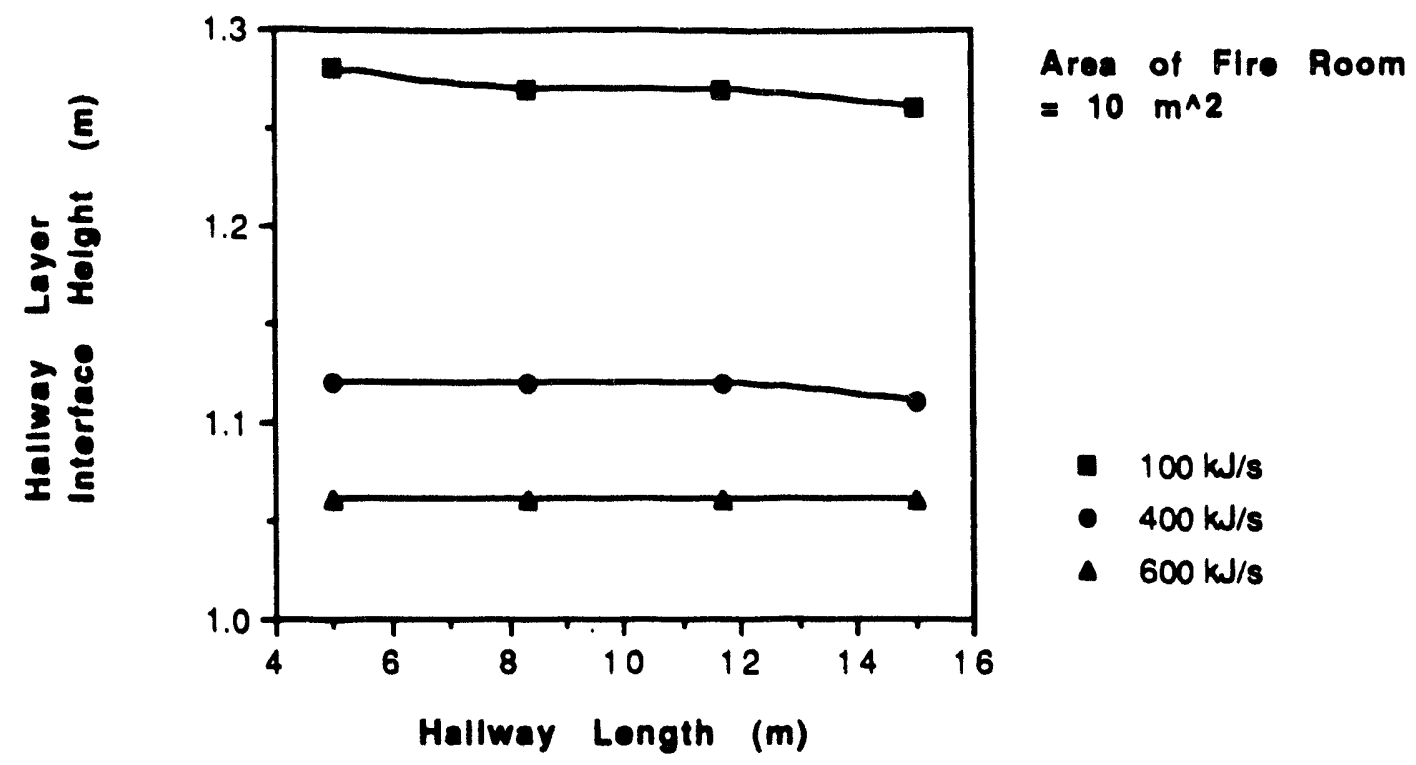

Figure 3-5

Hallway Layer Interface Height at $600 \mathrm{~s}$ (10 m² Fire Room).

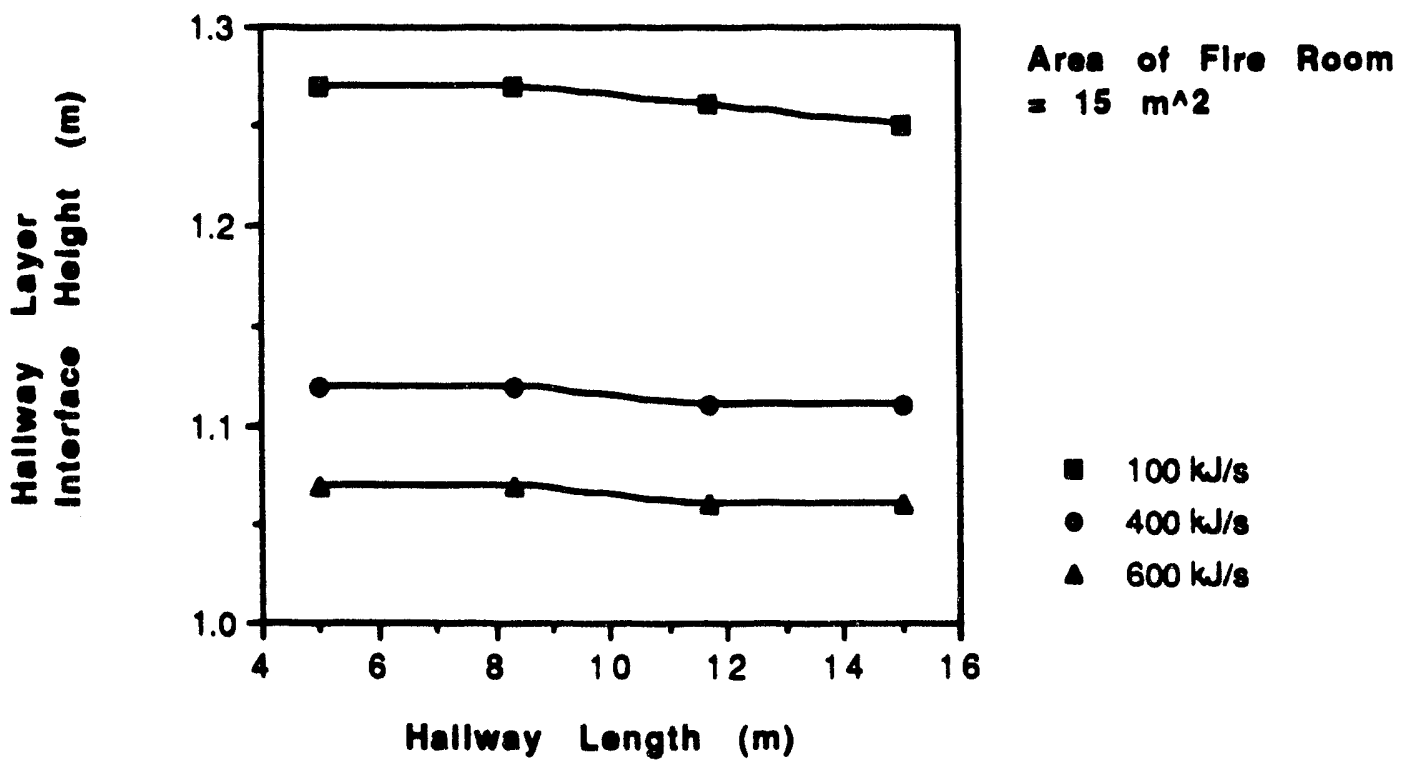

Figure $3-6$

Hallway Layer Interface Height at $600 \mathrm{~s}\left(15 \mathrm{~m}^{2}\right.$ Fire Room). 


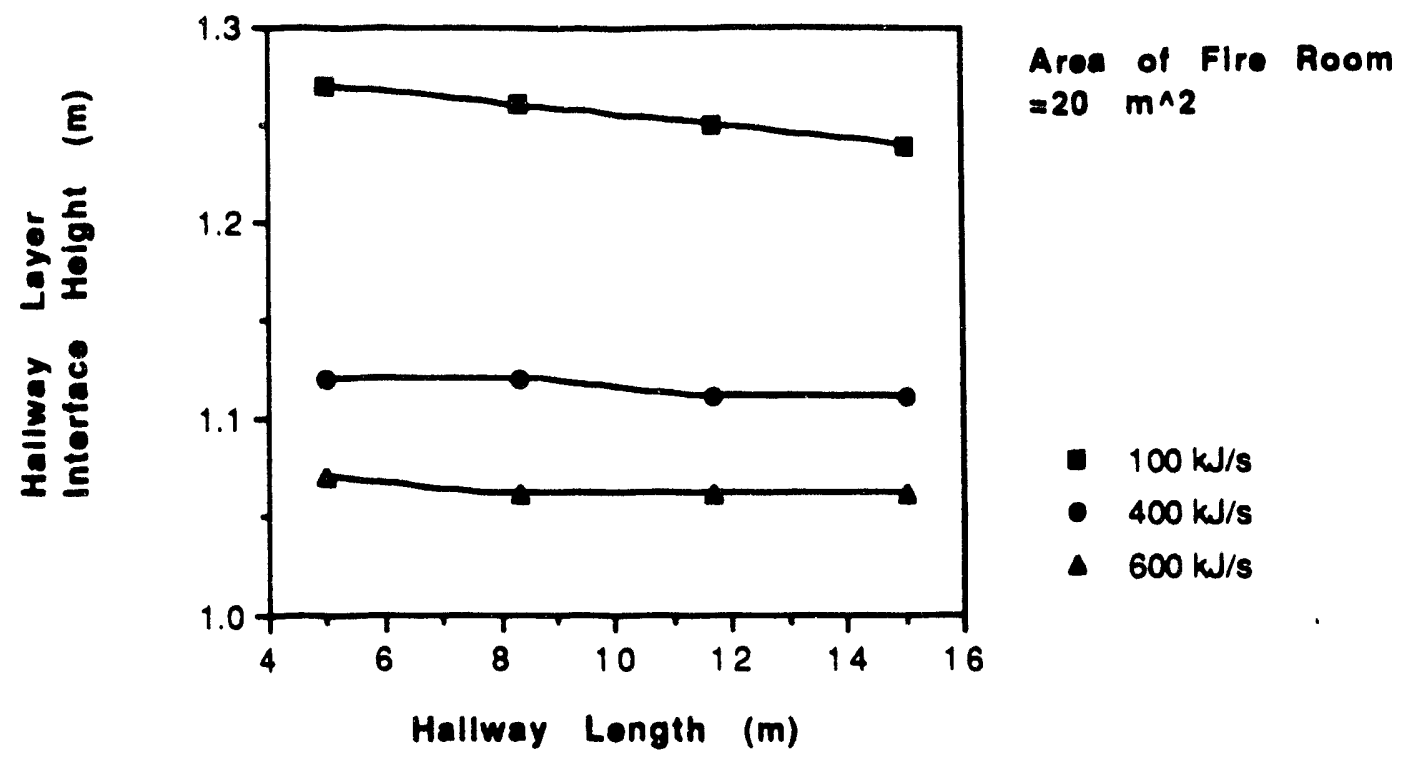

Figure 3-7

Hallway Layer Interface Feight at $600 \mathrm{~s}$ (20 m' Fire Room).

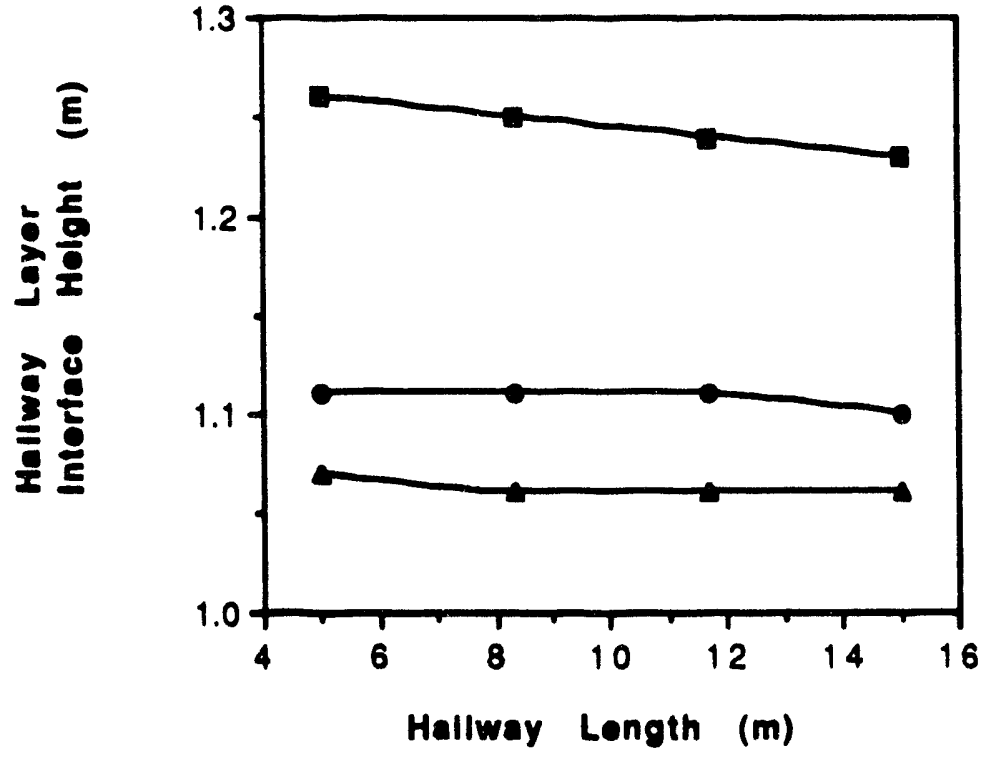

Area of Fire Room

$=25 m^{\wedge} 2$

- $100 \mathrm{~kJ} / \mathrm{s}$

- $400 \mathrm{~kJ} / \mathrm{s}$

- $600 \mathrm{~kJ} / \mathrm{s}$

Figure 3-8

Hallway Layer Interface Height at $600 \mathrm{~s}$ (25 m² Fire Room). 


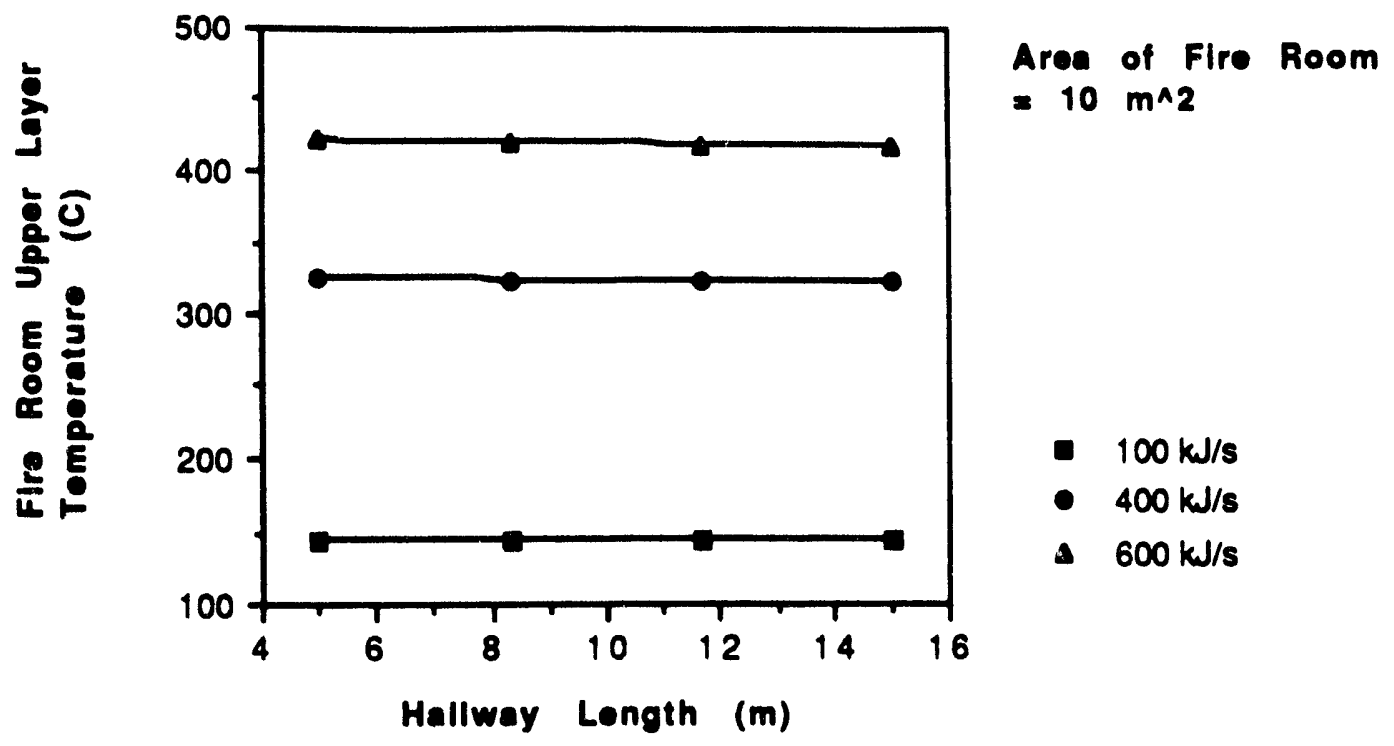

Figure 3-9

Fire Room Upper Layer Temperature at $600 \mathrm{~s}$ (10 m² Fire Room).

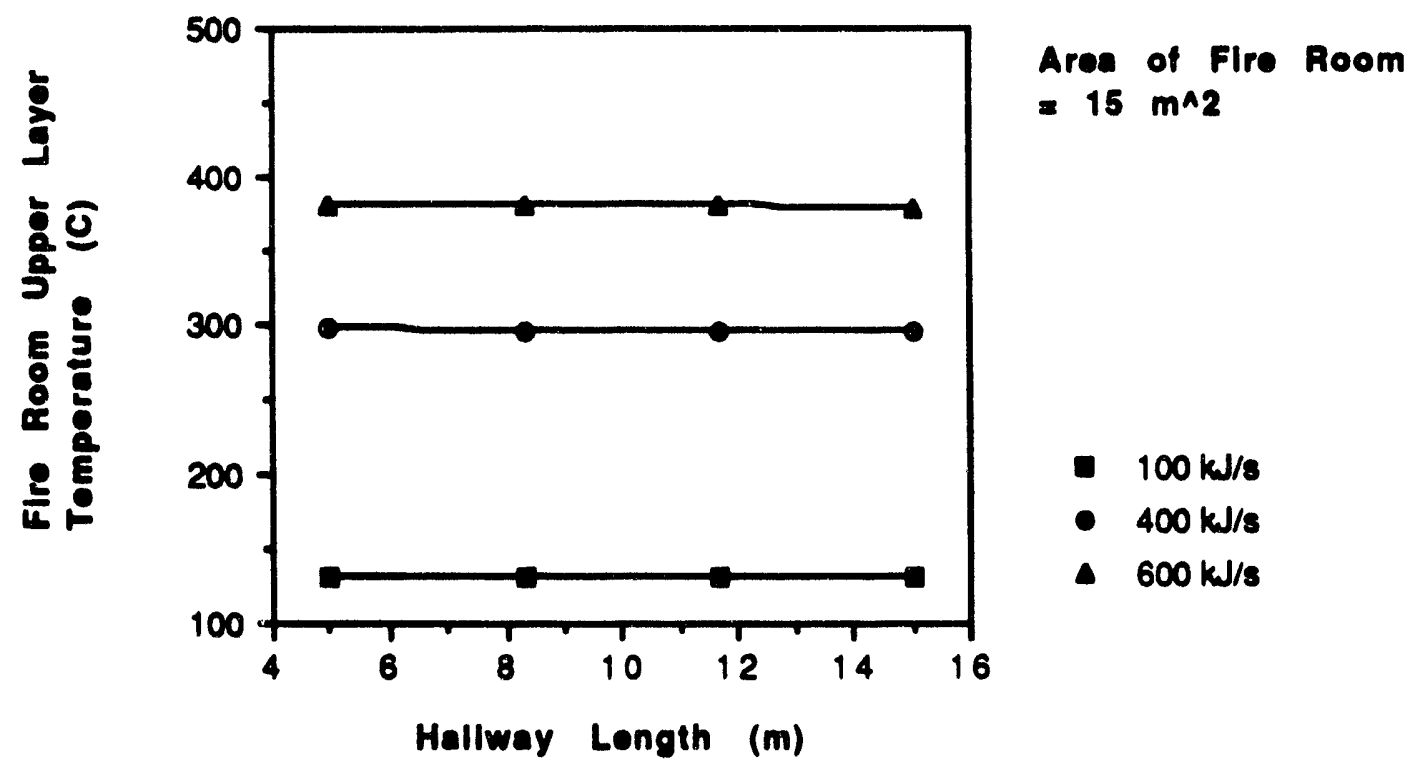

Figure 3-10

Fire Room Upper Layex Temperature at $600 \mathrm{~s}$ (15 m² Fire Room). 


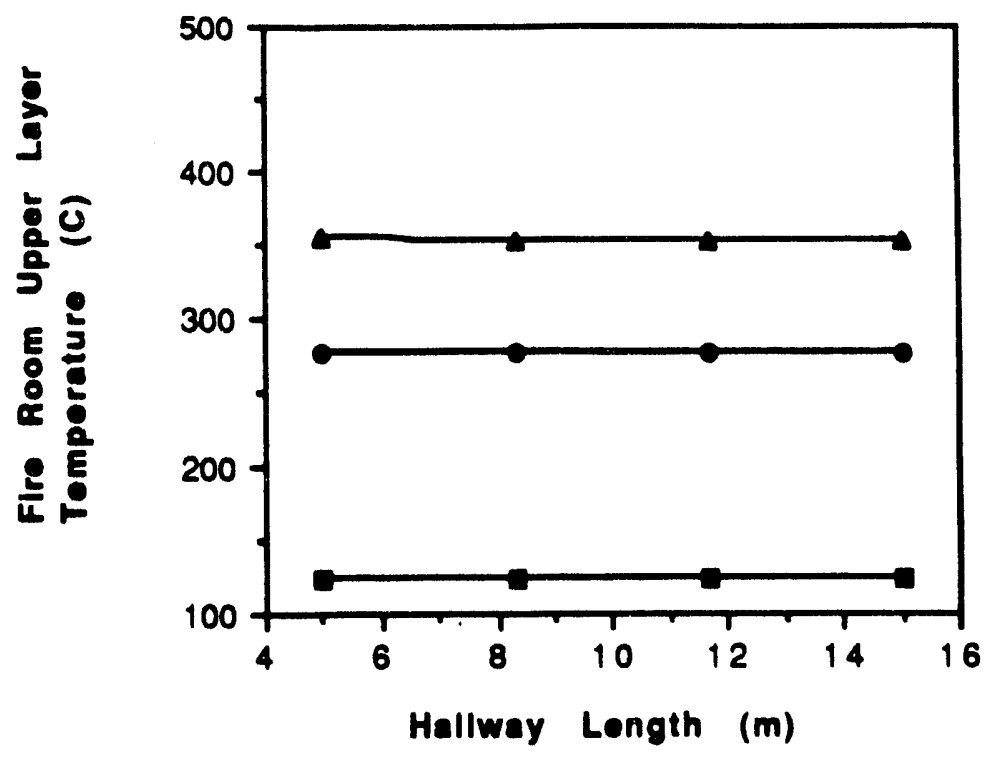

Aree of Fire Room

$=20 m^{\wedge} 2$

- $100 \mathrm{~kJ} / \mathrm{s}$

- $400 \mathrm{~kJ} / \mathrm{s}$

- $600 \mathrm{~kJ} / \mathrm{s}$

Figure 3-11

Fire Room Upper Layer Temperature at $600 \mathrm{~s}\left(20 \mathrm{~m}^{2}\right.$ Fire Room).

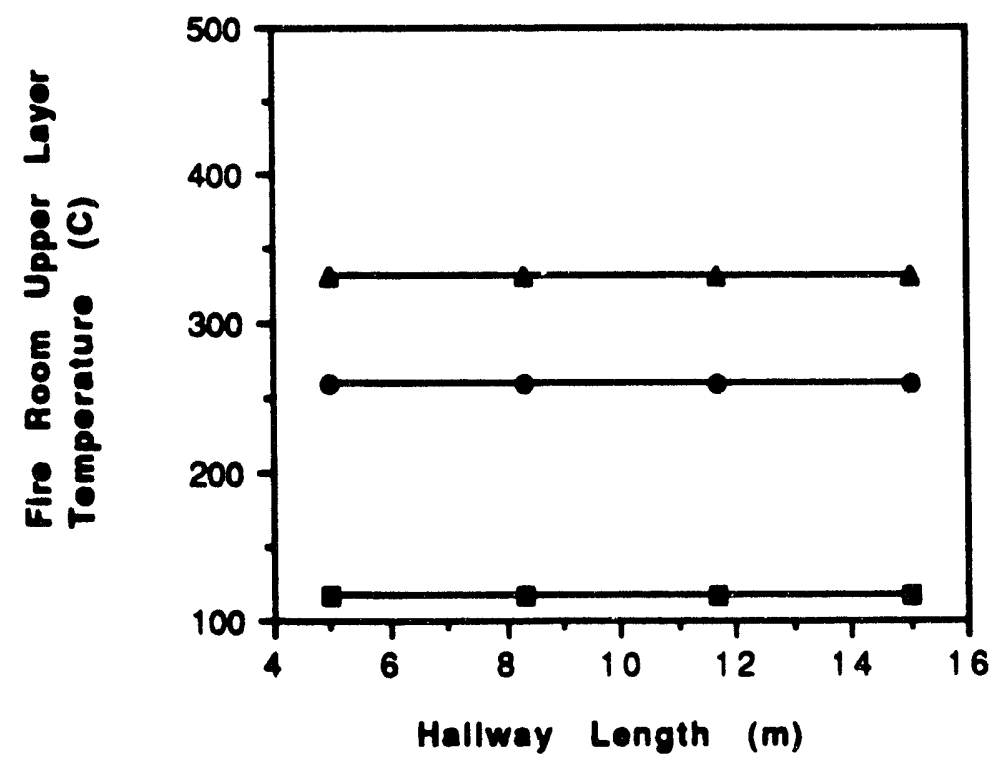

Area of Fire Room

- 25 ma2

- $100 \mathrm{~kJ} / \mathrm{s}$

- $400 \mathrm{~kJ} / \mathrm{s}$

- $600 \mathrm{~kJ} / \mathrm{s}$

Figure 3-12

Fire Room Upper Layer Temperature at $600 \mathrm{~s}$ (25 $\mathrm{m}^{2}$ Fire Room). 

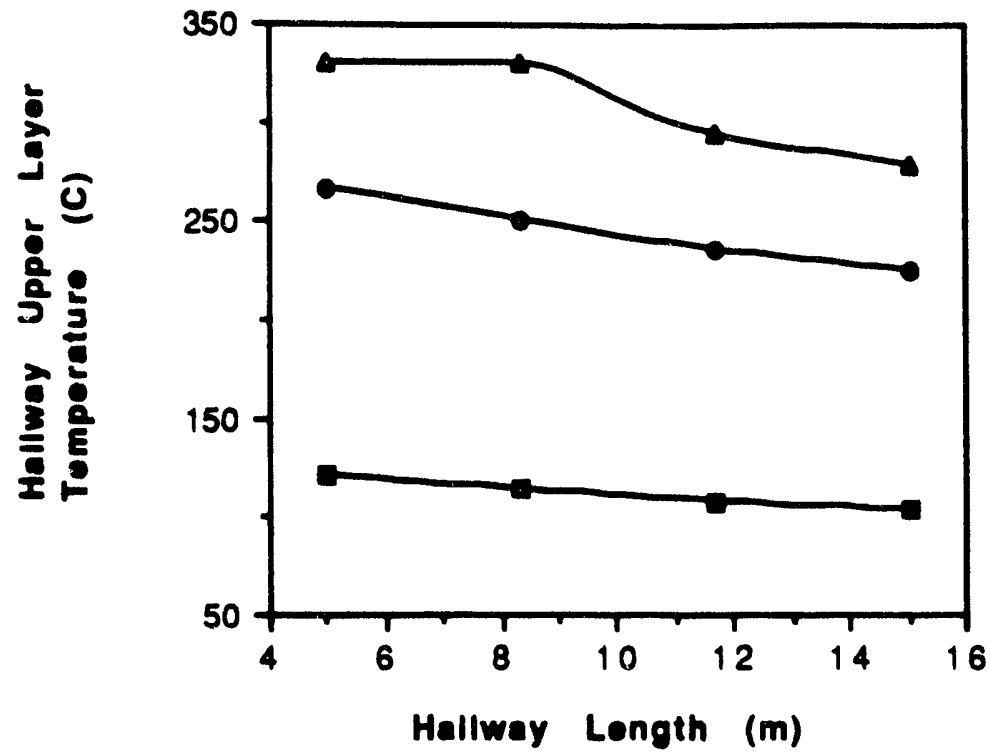

Aree of Fire Room $=10 \mathrm{~m}^{\wedge} 2$

- $100 \mathrm{~kJ} / \mathrm{s}$

- $400 \mathrm{~kJ} / \mathrm{s}$

- $600 \mathrm{~kJ} / \mathrm{s}$

Figure 3-13

Hallway Upper Layer Temperature at $600 \mathrm{~s}\left(10 \mathrm{~m}^{2}\right.$ Fire Room).

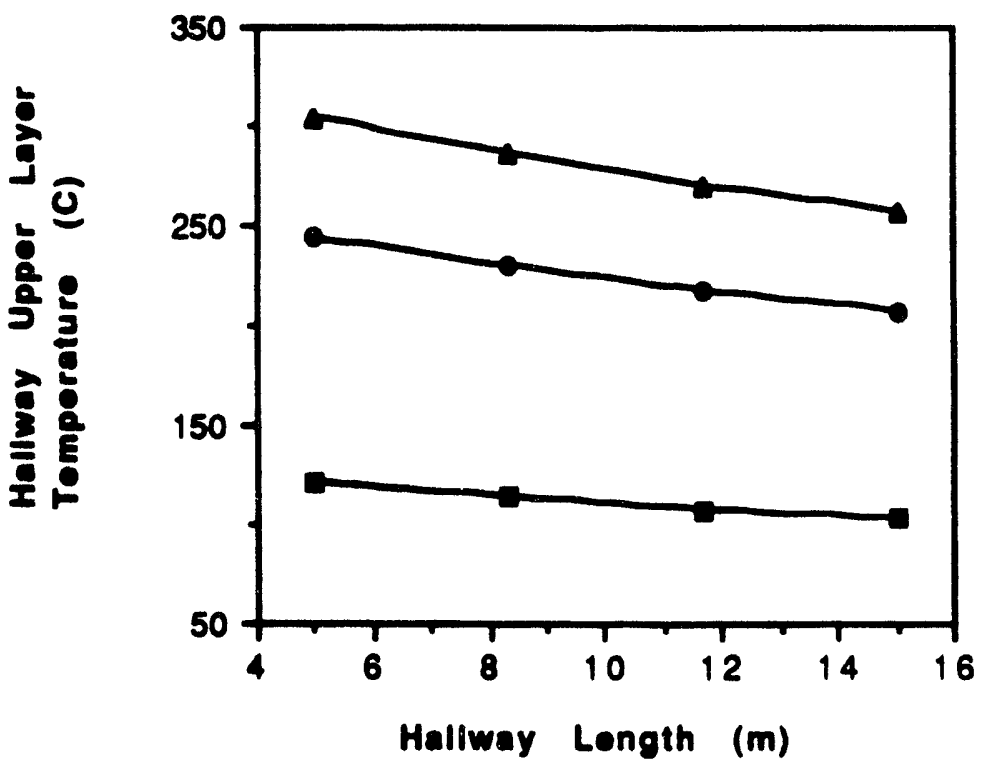

Ares of Fire Room

$=15 \mathrm{~m}^{\wedge} 2$

Figure 3-14

Hallway Upper Layer Temperature at $600 \mathrm{~s}$ (15 m² Fire Room). 


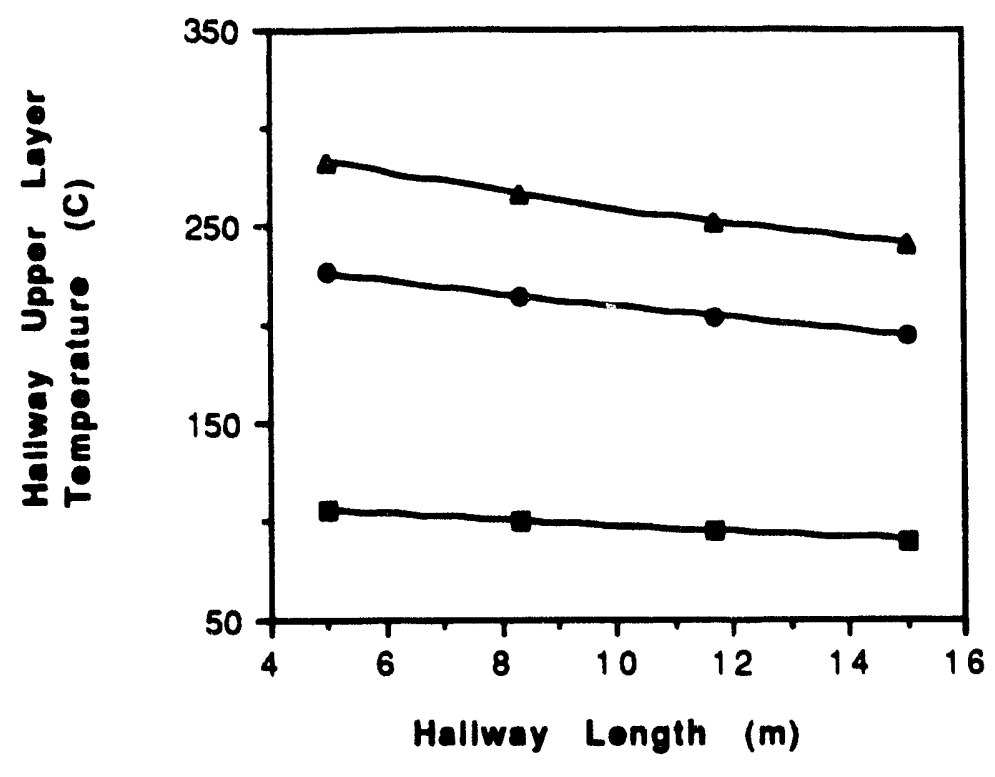

Area of Fire Room

$=20 \mathrm{~m} \wedge 2$

- $100 \mathrm{~kJ} / \mathrm{s}$

- $400 \mathrm{~kJ} / \mathrm{s}$

- $600 \mathrm{~kJ} / \mathrm{s}$

Figure 3-15

Hallway Upper Layer Temperature at $600 \mathrm{~s}\left(20 \mathrm{~m}^{2}\right.$ Fire Room).

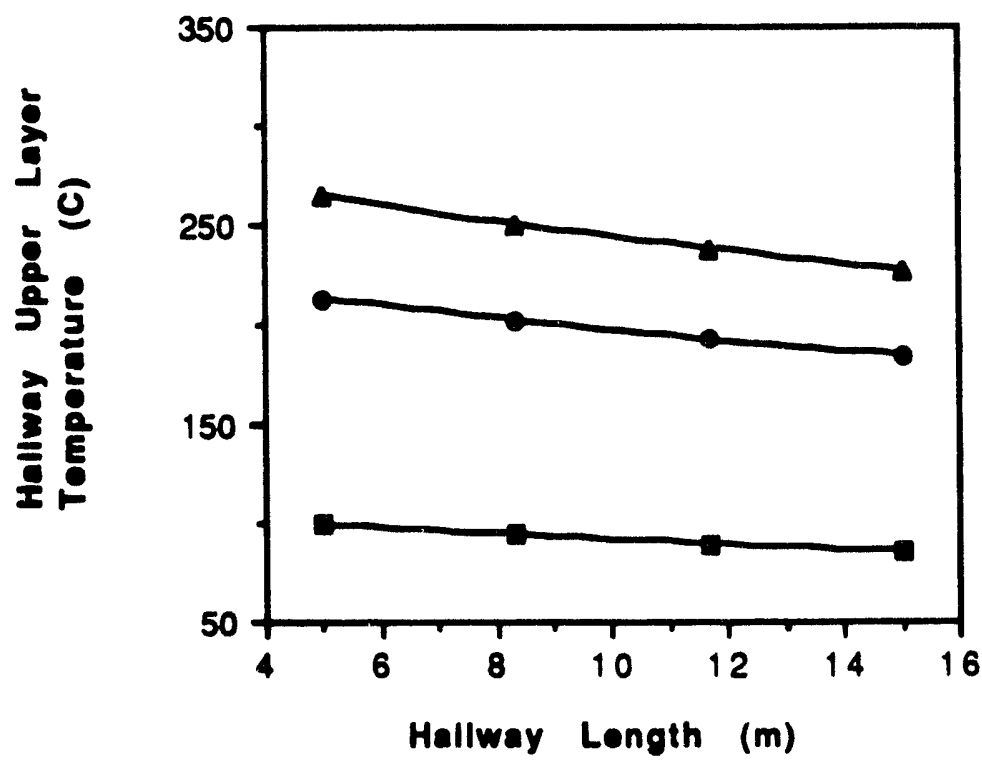

Aree of Fire Room

$=25 m^{\wedge} 2$

Figure 3-16

Hallway Upper Layer Temperature at $600 \mathrm{~s}$ (25 $\mathrm{m}^{2}$ Fire Room). 
WSRC·RP-83-1315

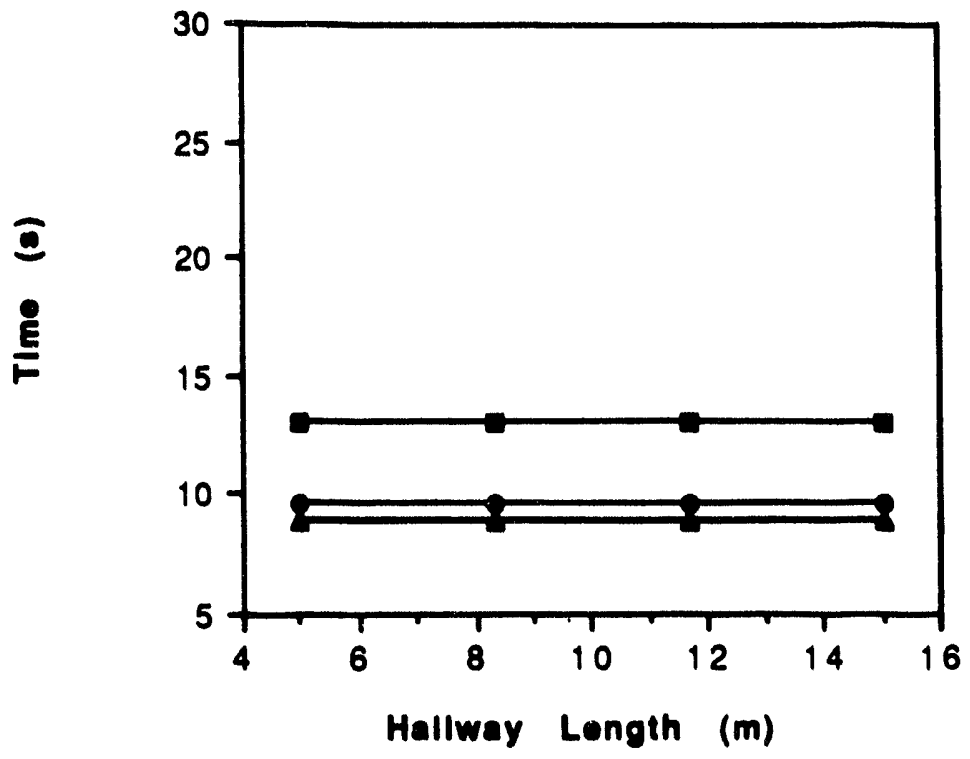

Area of Fire Room

$=10 \mathrm{~m}^{\wedge} 2$

- $100 \mathrm{~kJ} / \mathrm{s}$

- $400 \mathrm{~kJ} / \mathrm{s}$

- $600 \mathrm{~kJ} / \mathrm{s}$

Figure 3-17

Time for Layer Interface Height to Drop to $1.75 \mathrm{~m}$ in the Fire Room, (10 m² Fire Room).

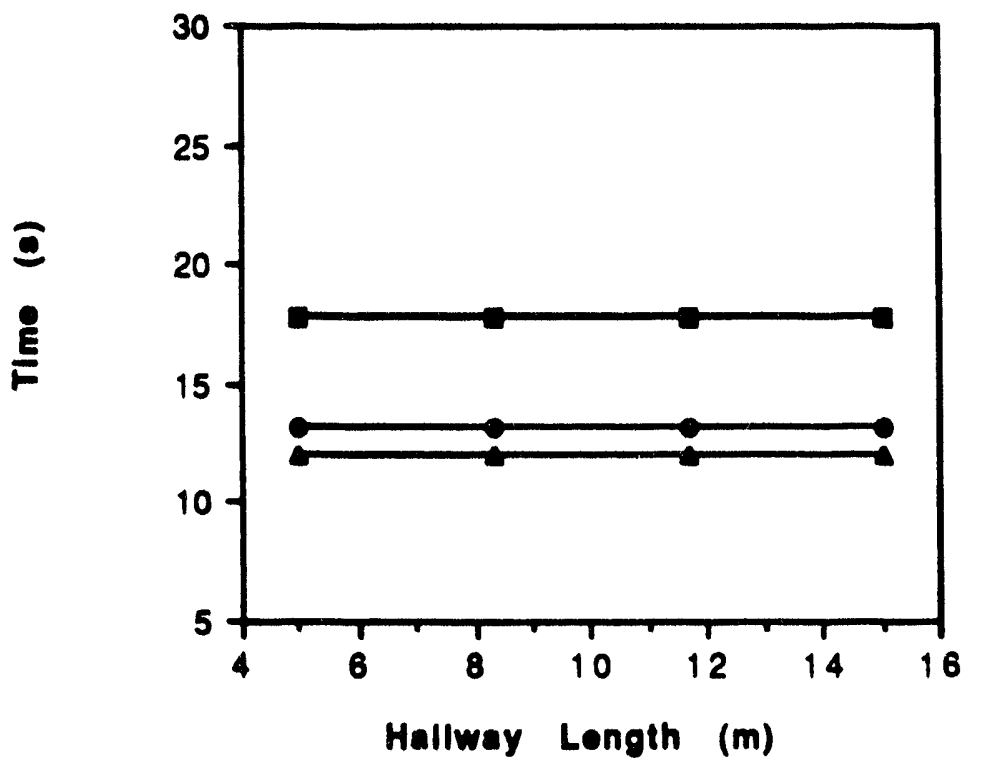

Area of Fire Room

- $15 \mathrm{~m}^{\wedge} 2$

- $100 \mathrm{~kJ} / \mathrm{s}$

- $400 \mathrm{~kJ} / \mathrm{s}$

- $600 \mathrm{~kJ} / \mathrm{s}$

Figure 3-18

Time for Layer Interface Height to Drop to $1.75 \mathrm{~m}$ in the Fire Room, (15 m² Fire Room). 


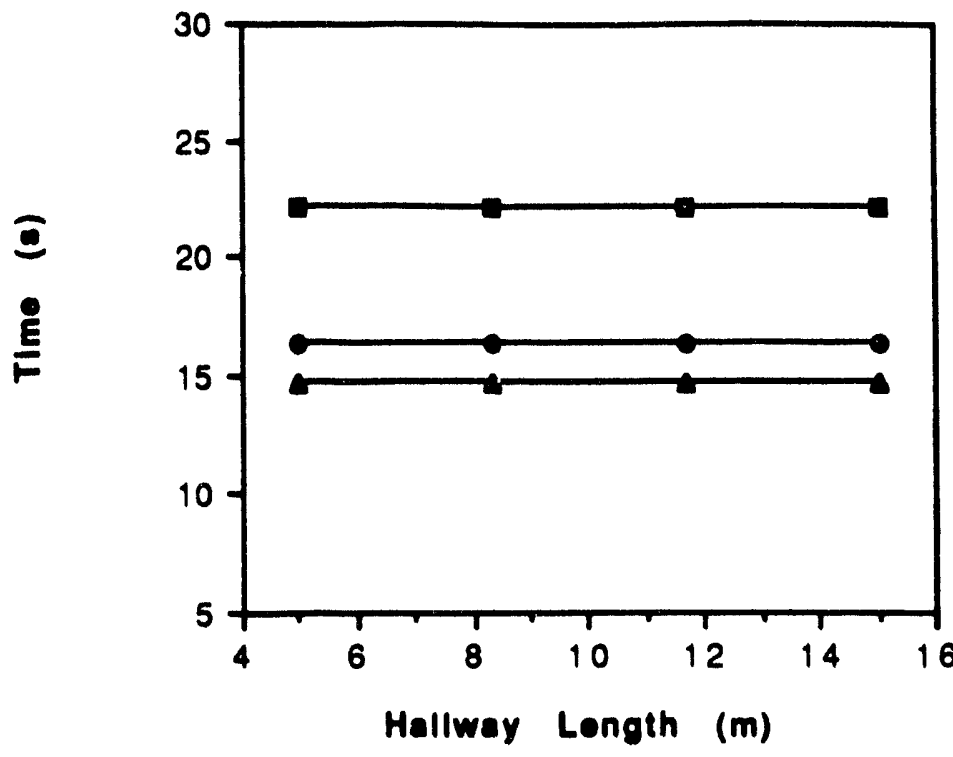

Area of Fire Room

$=20 \mathrm{~m} \wedge 2$

- $100 \mathrm{~kJ} / \mathrm{s}$

- $400 \mathrm{~kJ} / \mathrm{s}$

- $600 \mathrm{~kJ} / \mathrm{s}$

Figure 3-19

Time for Layer Interface Height to Drop to $1.75 \mathrm{~m}$ in the Fire Room, (20 m² Fire Room).

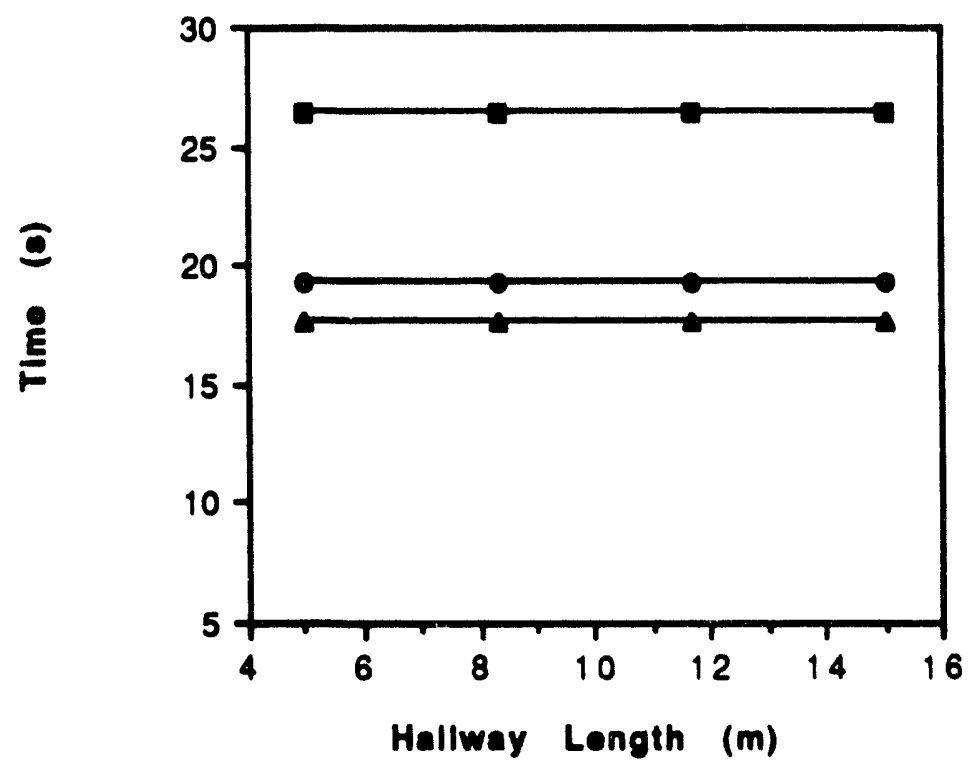

Area of Fire Room

$=25 \mathrm{~m}^{\wedge} 2$

- $100 \mathrm{~kJ} / \mathrm{s}$

- $400 \mathrm{~kJ} / \mathrm{s}$

- $600 \mathrm{~kJ} / \mathrm{s}$

Figure 3-20

Time for Layer Interface Height to Drop to $1.75 \mathrm{~m}$ in the Fire Room, (25 $\mathrm{m}^{2}$ Fire Room). 
WSRC-RP.83-1315

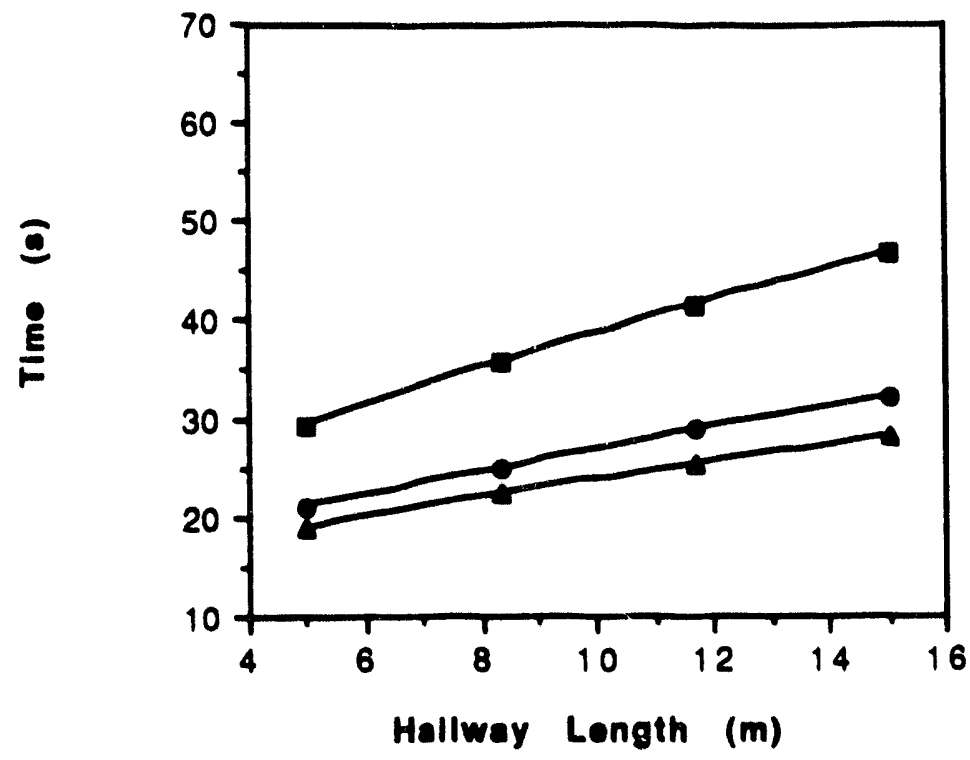

Area of Fire Room

$=10 \mathrm{~m}^{\wedge} 2$

- $100 \mathrm{~kJ} / \mathrm{s}$

- $400 \mathrm{~kJ} / \mathrm{s}$

- $600 \mathrm{~kJ} / \mathrm{s}$

Figure 3-21

Time for Layer Interfece Heicht to Drop to $1.75 \mathrm{~m}$ in the Hallway, (10 m Fire Room).

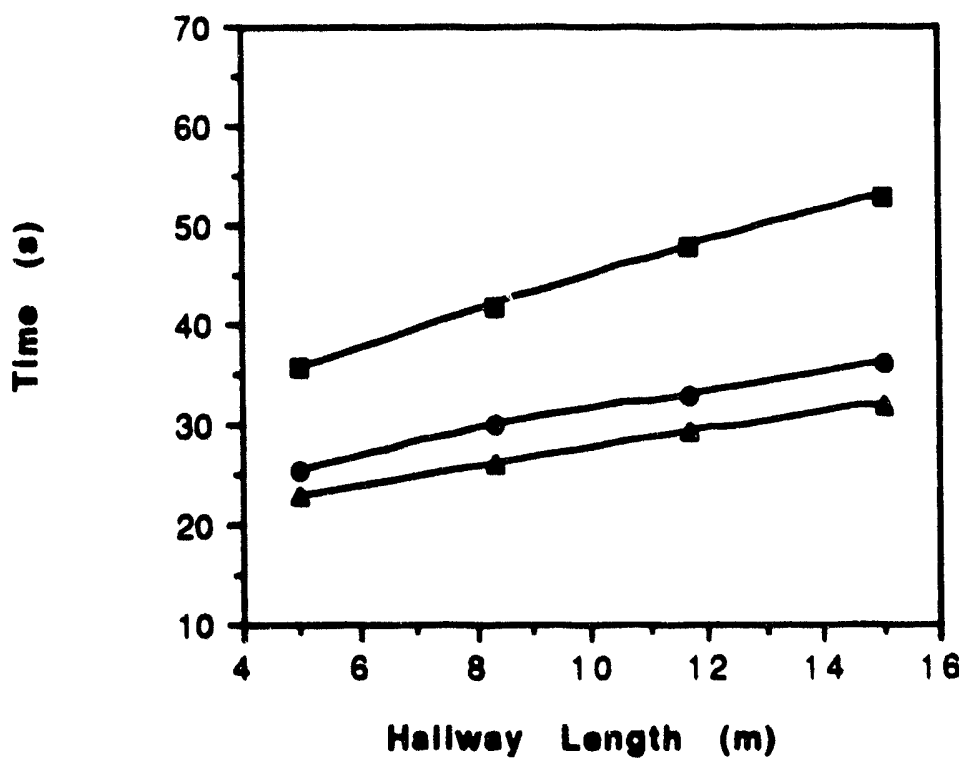

Aree of Fire Room

$=15 \mathrm{~m}^{\wedge} 2$

- $100 \mathrm{~kJ} / \mathrm{s}$

- $400 \mathrm{~kJ} / \mathrm{s}$

- $600 \mathrm{~kJ} / \mathrm{s}$

Figure $3-22$

Time for Layer Interface Feight to Drop to $1.75 \mathrm{~m}$ in the Hallway, (16 $\mathrm{m}^{2}$ Fire Room). 
WSRC-RP.83-1315

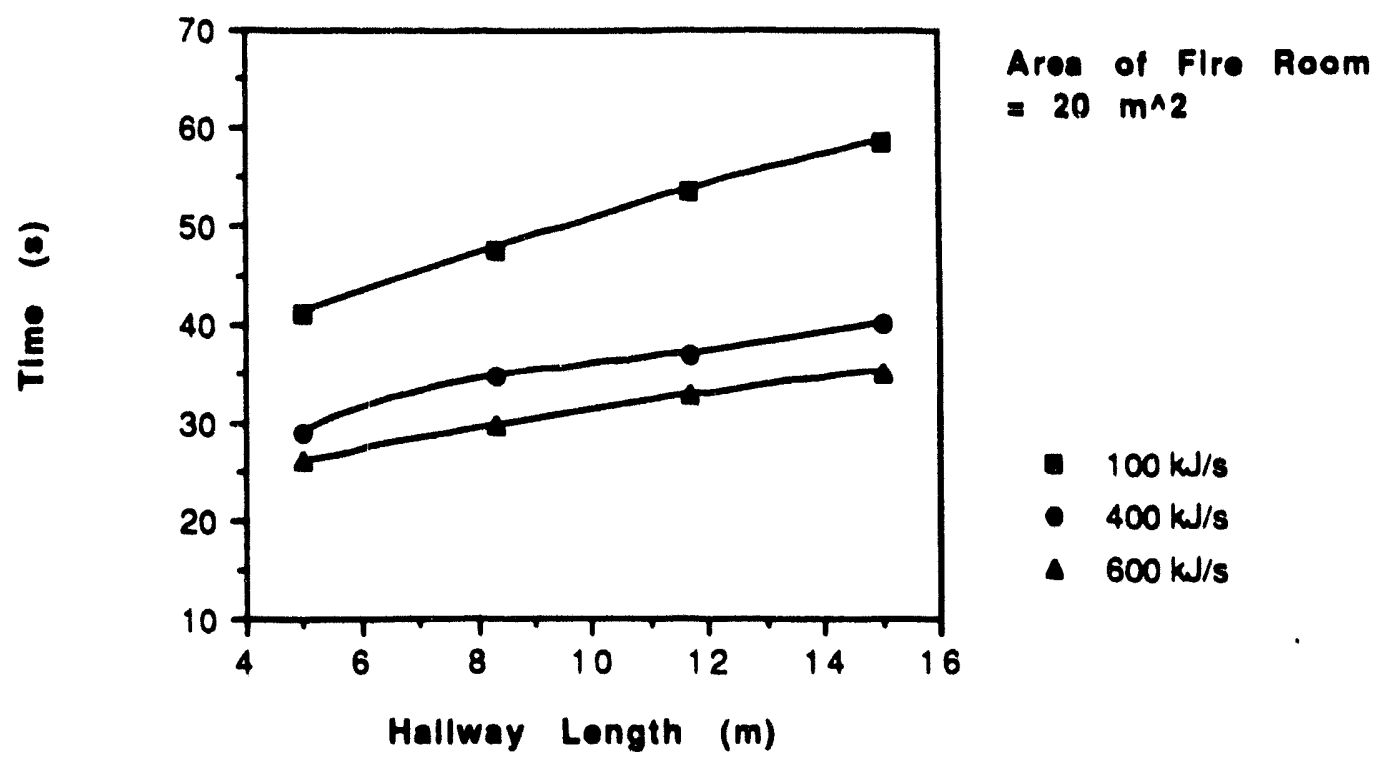

Figure 3-23

Time for Layer Interface Height to Drop to $1.75 \mathrm{~m}$ in the Halkway, (20 m² Fire Room).

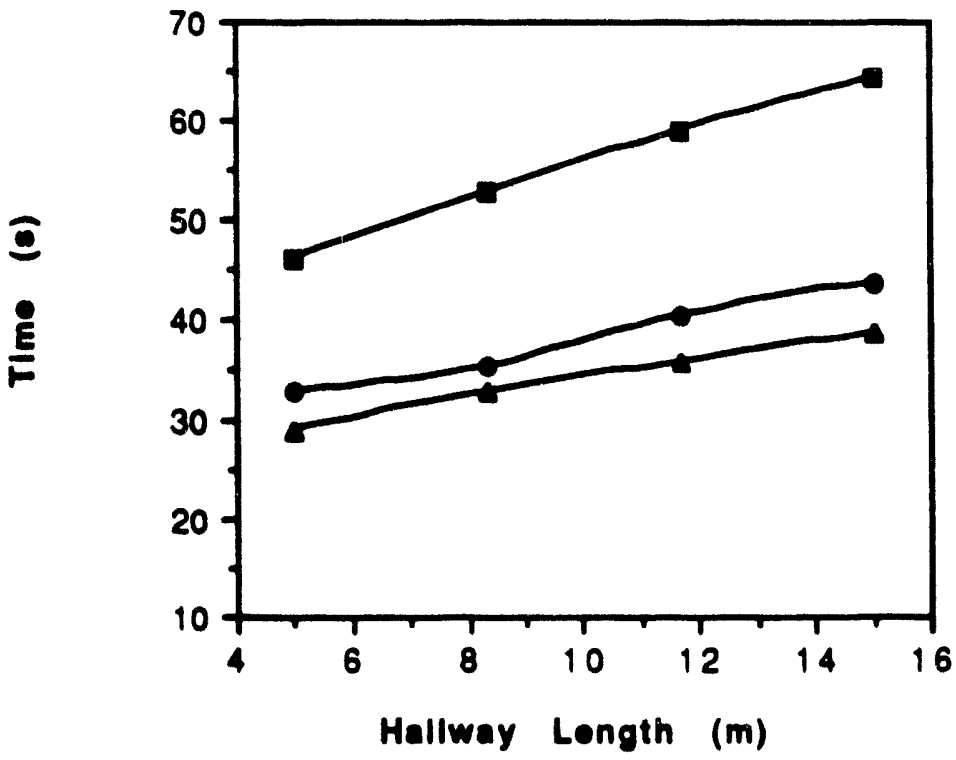

Area of Fire Room

- 25 m^2

Figure 3-24

Time for Layer Interface Height to Drop to $1.75 \mathrm{~m}$ in the Hallway, (25 m² Fire Room). 
WSRC-RP.89-1315

This page intentionally left blank. 
WSRC·RP.83-1315

\subsection{CONCLUSIONS AND RECOMMIENDATIONS}

The layer interface height and upper layer temperature were determined for a parametric CFAST two-room model that represented an office and hallway. Based on the results of the parametric study, the following conclusions are drawn:

- The dominant parameter affecting the layer interface height and upper layer temperature in both the fire room and the hallway is the fire heat generation rate.

- The hallway length has little if any effect on the layer interface height or the upper layer temperature in the fire room at steadystate conditions nor does it influence the time it takes for the layer interface in the fire room to drop to $1.75 \mathrm{~m}$.

- In general, increasing the area of the fire room or the hallway length will cause the layer interface to attain a higher steady-state height and take longer to drop to $1.75 \mathrm{~m}$, as well as causing a decrease in the upper layer temperature.

- In general, increasing the fire heat generation rate will cause the layer interface to attain a lower steady-state height and take less time to drop to $1.75 \mathrm{~m}$, as well as causing an increase in the upper layer temperature.

As this was a first attempt at developing a meaningful set of smoke propagation parameters, there is further work that could be performed to extend the current study. This work includes the following tasks:

- Run more test cases, both within and outside the bounds of the current parameters. The conclusions drawn above are based on somewhat sparse data. A wider range of test results would give a better overall picture of the how the parameters of interest influence smoke propagation.

- Refine the fire model; currently, the fire model ramps up to a constant heat generation rate and assumes that the fire is unconstrained. A more physically realistic model would increase the applicability of the results generated by the parametric model.

- Expand the model geometry. The effects of additional rooms adjacent the hallway could be analyzed.

- Investigate the effects of changes to the ventilation system flows and/or configuration. The flow rates could be altered parametrically for a give geometry, or additional vent paths could be added to model a more complex ventilation system. 
WSRC.RP.83-1315

- Verify the current model against experimental data. Ultimately, the results of this work need to be verified if they are to be used in evaluations involving life safety. 


\subsection{RHFERENCES}

1) R. D. Peacock, et al., CFAST, the Consolidated Model of Fire Growth and Smoke Transport, NIST Technical Note 1299, National Institute of Standards and Technology (February 1993).

2) W. W. Jones, "A Multicompartment Model for the Spread of Fire, Smoke, and Toxic Gases", Fire Safety Journal, 9(55) (1985).

3) G. P. Forney and L. Y. Cooper, The Consolidated Compartment Fire Model (CCFN) Computer Application CCFM.VENTS - Part II: Software Reference Guide, National Institute of Standards and Technology, NISTIR 90-4343 (1990).

4) E. A. Avallone and T. Baumeister III, Marks' Standard Handbook for Mechanical Engineers, Ninth Edition, McGraw Hill Book Co., New York, New York (1987). 
WSRC-RP-93-1315

This page intentionally left blank. 


\section{Internal Distribution}

Westinghouse Savannah River Company

R. T. Bailey, 992W-1

F. Beranek, 773-A'

D. A. Coutts, $992 W-1$

M. L. Cowen, 992W-1*

R. R. Fayfich, 730-B

M. J. Hitchler, 992W-1*

D. A. Kalinich, $992 \mathrm{~W}-1$

D. E. McAfee, 730-B

J. D. Menna, $992 W-1^{*}$

K. R. O'Kula, 992W-1

S. R. Salaymeh, $992 \mathrm{~W}-1^{*}$

Central Records Facility, 772-53A (4)

\section{External Distribution}

Mark D. Brandyberry, SAIC

- Executive Summary Only 

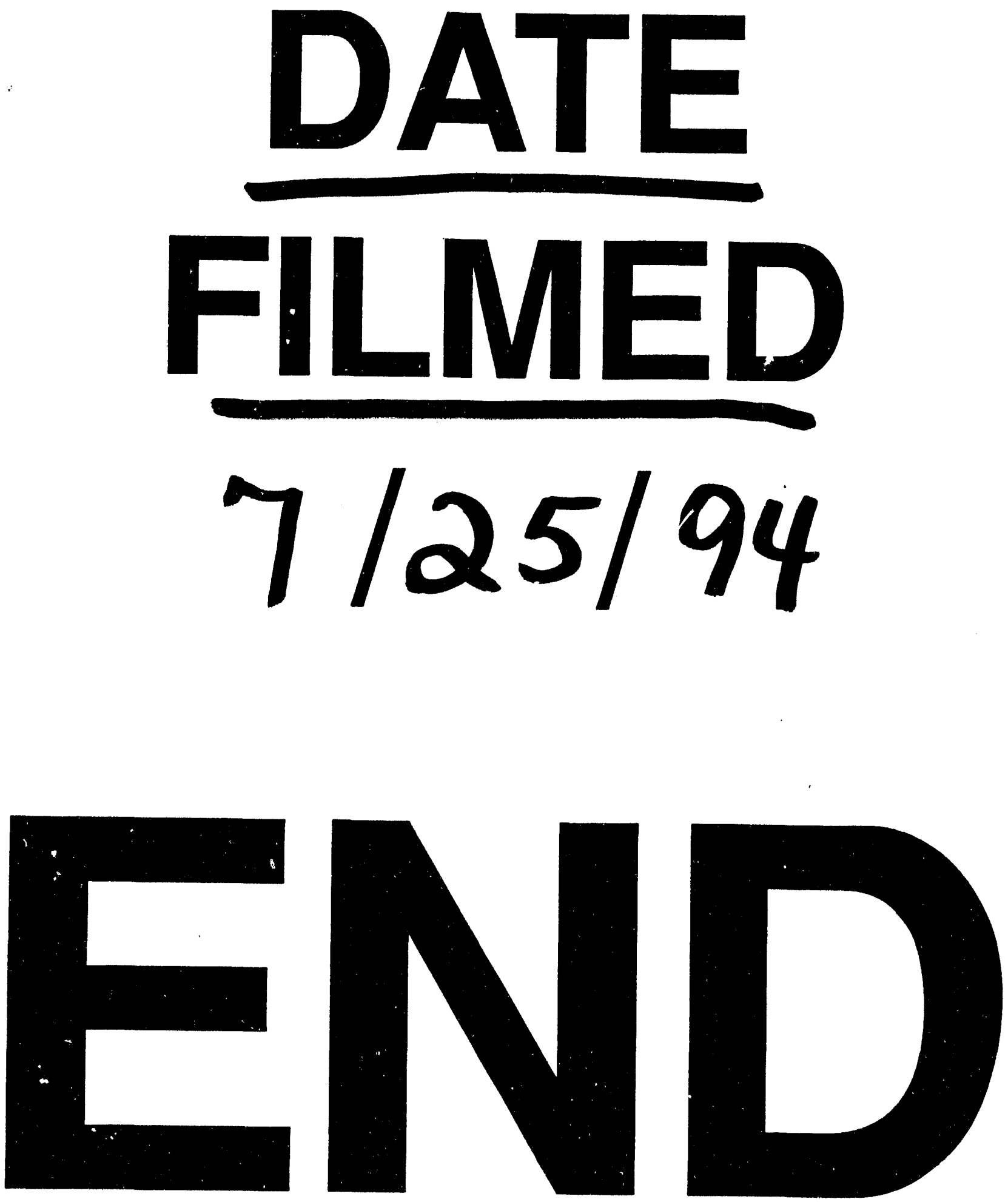
